\title{
The Risk of Being Ranked: Investor Response to Marginal Inclusion on the 100 Best Corporate Citizens List
}

\author{
Ben William Lewis \\ blewis@byu.edu \\ W. Chad Carlos \\ Brigham Young University, chad_carlos@byu.edu
}

Follow this and additional works at: https://scholarsarchive.byu.edu/facpub

Part of the Corporate Finance Commons

\section{BYU ScholarsArchive Citation}

Lewis, Ben William and Carlos, W. Chad, "The Risk of Being Ranked: Investor Response to Marginal Inclusion on the 100 Best Corporate Citizens List" (2018). Faculty Publications. 2064.

https://scholarsarchive.byu.edu/facpub/2064 


\title{
THE RISK OF BEING RANKED: INVESTOR RESPONSE TO MARGINAL INCLUSION ON THE 100 BEST CORPORATE CITIZENS LIST
}

\author{
Ben W. Lewis \\ Marriott School of Business \\ Brigham Young University \\ 565 TNRB \\ Provo, UT 84602 \\ blewis@byu.edu \\ (801) 422-2308 \\ W. Chad Carlos \\ Marriott School of Business \\ Brigham Young University \\ 687 TNRB \\ Provo, UT 84602 \\ chad_carlos@byu.edu \\ (801) 422-7989
}

The final definitive version of this paper will be forthcoming in the Strategic Management Journal Special Issue on Question-Driven and Phenomenon-Based Empirical Strategy Research. This article may be used for non-commercial purposes in accordance with Wiley Terms and Conditions for Self-Archiving. Individuals who would like to obtain an electronic copy of the final published manuscript may email the authors directly. 
Research Abstract: Despite the proliferation of lists and rankings that recognize firms for superior performance, empirical studies have been limited in their ability to causally evaluate how inclusion for the marginal firm influences shareholder value. Using a regression discontinuity design, we address this limitation by examining how investors responded to firms that were just barely included or excluded from the 100 Best Corporate Citizens list. Contrary to prevailing theoretical expectations, our findings indicate that marginal firms that were included in the ranking experienced negative abnormal returns compared to marginal firms that were excluded. We discuss how these findings inspire future research on rankings and status and highlight implications for managers considering strategic decisions related to pursuing rankings.

Managerial Abstract: Because being ranked is generally seen as an important strategic objective for companies, executives must carefully consider how much attention and resources to allocate towards this pursuit. Although existing research suggests that being ranked can be beneficial, we have a limited understanding about whether barely making a ranked list is worth the effort. We provide new insights for executives by showing that investors respond negatively to marginal inclusion on a ranking but also provide suggestions for how companies might counteract this effect. Specifically, our results suggest that making consistent, focused investments that are relevant to external stakeholders may buffer organizations from the potential negative effects of marginal inclusion on a ranking. These insights may also inspire executives to reconsider their firms' commitments to being ranked.

Keywords: rankings, status, reputation, regression discontinuity, corporate social responsibility

\section{INTRODUCTION}

Corporate lists that rank and recognize firms for superior performance have proliferated in recent years (Espeland and Sauder, 2016; Fombrun, 2007; Sadowski, Whitaker, and Buckingham, 2010). Consistent with this trend, an increasing number of CEOs and other top managers are prioritizing efforts to gain inclusion on such lists (Gunther, 2010; Lewis, Walls, and Dowell, 2014; Sadowski, 2010). Indeed, a quick glance at annual reports of large public corporations reveals an intense competition among companies for inclusion on prominent rankings such as the 100 Best Places to Work (Dineen and Allen, 2016), the Dow Jones Sustainability Index (Carlos and Lewis, 2018; Hawn, Chatterji, and Mitchell, 2018), or the 100 Best Corporate Citizens list (Brammer, Brooks, and Pavelin, 2009). These trends suggest that managers see rankings as a valuable strategic asset and will invest significant resources and attention towards inclusion on these prestigious lists (Espeland and Sauder, 2007). 
To date, the literature on rankings has generally assumed that the consequence of inclusion on a ranked-list is bimodal in that it produces unequal benefits for ranked firms relative to the unranked (Azoulay, Stuart, and Wang, 2014; Merton, 1968; Podolny, 2010) and that this effect is most salient for firms at the margins. Referred to as "the Matthew effect" (Merton, 1968: 3), this notion that rankings produce disproportionate compounding benefits to award recipients compared with essentially equivalent unrecognized peers has largely become taken for granted by both scholars and practitioners (Piezunka et al., 2018; Reschke, Azoulay, and Stuart, 2017). Despite these prevailing theoretical assumptions, few empirical analyses have been able to causally examine whether marginal inclusion on a ranked list is beneficial. Consequently, companies often seek recognition "without clearly knowing whether they will derive benefits" or "whether recognition has potential downsides" (Dineen and Allen, 2016: 92). This raises an important empirical question: Are companies that are on the margin better off being included or excluded from a ranked list? ${ }^{1}$

To address this question, we examine how investors respond to firms' marginal inclusion on a prestigious ranking. Although other studies have examined the average effect of being ranked (Brammer et al., 2009; Edmans, 2011; Klassen and McLaughlin, 1996; Lyon and Shimshack, 2015), most have been limited in their ability to draw causal inferences about firms on the margin, primarily because they have not been able to access the list of firms that were barely excluded (Hawn et al., 2018). We address this methodological limitation by examining the effect of inclusion on shareholder value for marginal firms that barely make or barely miss the Best

\footnotetext{
${ }^{1}$ We define a ranking as relative rank-ordering of actors against one another that confers award like status upon recipients (Graffin and Ward, 2010). We also distinguish rankings from ratings or accreditations where organizations are assessed relative to a general standard instead of being compared against other organizations under consideration. Although some rankings may include all firms under consideration, we focus exclusively on those that are finite in length (i.e. lists) and have a defined threshold for inclusion (e.g. Best 100, Top 50, etc.) (Rossman and Schilke, 2014). Consequently, we use the terms "rankings" and "lists" interchangeably.
} 
Corporate Citizens (100 BCC) list, a prominent ranking that evaluates the corporate social performance of public corporations. Because we are able to identify similar firms around the inclusion threshold, we can treat inclusion on the list as akin to a random assignment (Flammer, 2015a), a necessary element of causal inference. This approach of comparing outcomes for marginal firms around a discontinuous threshold is known as regression discontinuity (RD).

Our primary result departs from prevailing theoretical expectations and suggests that inclusion on the $100 \mathrm{BCC}$ list can in some cases decrease shareholder value for firms just above the threshold. On the day of announcement, we find that firms that barely make the list experience a negative $1.3 \%$ abnormal return relative to firms that barely miss the cut. To better understand the boundary conditions of this result, we also examine whether individual firm characteristics correlated with a firm's reputation for corporate social responsibility (CSR) may moderate how investors respond to the ranking. These effects, we maintain, help to explain why and when marginal firms might be buffered from negative evaluations by investors for just barely gaining inclusion in the ranking.

Theoretically, we believe that through a process of commensuration, ranking systems may distill and simplify complex information into a new category that groups together similar actors and allows for easier comparison of actors within that category (Bowers, 2015; Espeland and Stevens, 1998; Lee, Hiatt, and Lounsbury, 2017; Shocker et al., 1991). This comparison, we suspect, magnifies the relative weaknesses of bottom-ranked firms by making the performance disparity between and top-ranked firms more salient. Taken together, we suggest that the categorization and reevaluation of marginally ranked firms may lead to a liability of comparison whereby investors devalue low-ranked members of a high-status category (Leclerc, Hsee, and Nunes, 2005). 
In summary, we believe this surprising negative effect of marginal inclusion on a ranking has several important theoretical and practical implications for scholars and managers. First, these results motivate the reconsideration of common theoretical assumptions about the benefits of rankings and status and directly speak to recent work on unearned status gains and losses. Second, our findings help reconcile tension in the literature about the impact of CSR on firm performance by highlighting the need to distinguish between CSR implementation and CSR recognition. Third, our results suggest that marginally included firms may protect themselves from devaluations by taking a focused, consistent, and relevant approach to reputational investments. Although our primary result is not generalizable to all public firms, the fact that we do find robust support within this context suggests that similar findings may occur with other rankings. Given the proliferation of rankings, we thus call for scholars to perform additional studies to determine whether and when similar liabilities for marginally ranked firms might occur.

\section{THIRD-PARTY RECOGNITION AND SHAREHOLDER VALUE}

Research on the effects of third-party recognition paints a fairly consistent picture; receiving an award, making it on a prestigious list, or achieving a high rank are assumed to provide unequal benefits to winners, compared to similar others who are not recognized (Elsbach and Kramer, 1996; Rindova et al., 2005; Rossman and Schilke, 2014; Waguespack and Sorenson, 2011). Empirically, research on the financial effects of receiving awards generally supports these arguments. For example, studies indicate that investors respond positively to news about awards for diversity (Wright et al., 1995), quality (Hendricks and Singhal, 1996), and environmental performance (Klassen and McLaughlin, 1996). Other studies report financial benefits for organizations included on prominent lists such as the 100 Best Companies for Working Mothers 
(Jones and Murrell, 2001), the 100 Best Corporate Citizens (Brammer et al., 2009), and the 100 Best Companies to Work For (Edmans, 2011; Fulmer, Gerhart, and Scott, 2003). In general, these studies show that being included on a ranked list can generate significant short- and longterm financial benefits, even after controlling for other observable characteristics.

Given the purported benefits of third-party recognition, it should be of no surprise that companies and their executives increasingly strive to be recognized on such lists. Carlos and Lewis (2018), for example, noted how companies explicitly set goals to be included or remain on the Dow Jones Sustainability Index (DJSI). Dineen and Allen (2016), likewise, found that companies will spend significant amounts of time and resources and make substantial changes to their employee benefits in order to compete for a spot on a list such as Fortune's 100 Best Companies to Work For. Highlighting this motivation to be recognized, one critic commented that companies "put a lot of time into checking their data" and "do their best to hit the right data points" to increase their likelihood of inclusion (Gunther, 2010). Because of the importance that executives appear to place on such achievements, it is important to understand empirically whether inclusion on a ranked list actually matters.

Although companies are attracted to such lists for their obvious marketing appeal, few empirical investigations have convincingly addressed whether marginal inclusion on a prestigious list is actually beneficial (Dineen and Allen, 2016). To date, the primary research design employed to analyze the financial benefits of list inclusion has been an event study. While such studies can provide valuable information about the average effect of list inclusion, they typically do not evaluate the abnormal returns of similar companies that do not make the cut (Hawn et al., 2018), often because the information is proprietary or not available to the public. By ignoring the unranked or unlisted firms, researchers thus limit their ability to empirically 
examine whether a firm that barely makes a list is actually better off than a firm that is barely excluded. Indeed, such knowledge could be extremely valuable for managers who wonder if their firm's inclusion on a list will derive any benefits and question whether their firm should enter, re-enter, or exit these competitions (Dineen and Allen, 2016).

\section{DATA AND METHODS}

\section{Context}

To examine this empirical question, we study investor response to marginal inclusion on the 100 Best Corporate Citizens (100 BCC) list. Established by the magazine Business Ethics in the year 2000, the $100 \mathrm{BCC}$ list was the first prominent ranking of corporate citizenship for large public corporations. Certainly awards, prizes, and other forms of recognition were given for superior corporate citizenship prior to 2000 , but we found no evidence of a systematic evaluation and subsequent ranking of similar scale prior to the $100 \mathrm{BCC}$ list. $^{2}$

The stated objective of publicizing the $100 \mathrm{BCC}$ list was to "move corporations toward everbetter practices" by "pushing the envelope on what represents good citizenship" (Waddock, Graves, and Kelly, 2000: 17). Implicit in this statement is an assumption that being included on the list can generate substantial recognition and notoriety which can consequently spur imitation and improvement among the excluded firms (Fombrun, 1996; Lewis, 2017).

Although the 100 BCC list has been published annually since the year 2000, we focus our analysis on the initial year the list was published for three reasons. First, studying the emergence of a new ranking increases the likelihood of observing investors' reactions to novel information (Brammer et al., 2009), an essential assumption of an event study (McWilliams and Siegel,

\footnotetext{
${ }^{2}$ Other prominent lists in existence included the Domini Social 400 index, a stock index constructed in 1990 by KLD to track the costs and benefits of applying social criteria to investment (Godfrey, 2011), and the Dow Jones Sustainability Index (DJSI), established in 1999. Unlike the 100 BCC, the DS 400 and the DJSI were stock indices, not rankings. Consequently, an investor would only know whether a firm was included on the index, but would not know the firm's relative ranking within the index (Graffin and Ward, 2010).
} 
1997). Second, once the criteria for making the list is known, motivated firms may be able to game the system (Gunther, 2010) which could invalidate our assumption of quasi-randomized treatment (Lee and Lemieux, 2010), also an essential component of our research design. Focusing on the inaugural year thus reduces the chance that self-selection could bias our results. Third, using the initial year helps to isolate the effect of recognition bestowed by a ranking from other information about firm performance that may have been previously available.

The inaugural $100 \mathrm{BCC}$ ranking was constructed using social ratings data from the Kinder, Lydenberg, and Domini (KLD) Socrates database. At that time, KLD's evaluation universe included members of the S\&P 500 and Domini 400 indices (approximately 650 firms). Eligible firms were evaluated based on relations with communities, customers, employees, and shareholders from 1996-1998. An overall score was computed by averaging each category over the three-year period in order to smooth year-to-year fluctuations. We describe the rankings process and display a snapshot of the initial $100 \mathrm{BCC}$ list and breakdown by industry in Tables A1-A2 in the Appendix.

KLD evaluated 658 firms in 1998, the final data year used to construct the inaugural ranking in 2000. Of these 658 firms, 110 were not considered eligible because they had been evaluated by KLD less than the required three years. An additional seven firms were dropped from consideration because of recent events that would contradict the signal of superior corporate citizenship (Waddock et al., 2000). These removals left 541 firms that were evaluated and ranked by Business Ethics magazine. Of these remaining ranked firms, 28 had their stocks delisted prior to the announcement date largely because they were acquired. Our final sample consists of these 513 firms that were (1) ranked by Business Ethics and (2) had stocks that were actively being traded on the announcement day. 
Unlike prior research that has examined investor response to CSR rankings and lists (Brammer et al., 2009; Edmans, 2011; Fulmer et al., 2003; Hawn et al., 2018; Lyon and Shimshack, 2015), our identification strategy relies on understanding the social performance of firms that were not only included on the $100 \mathrm{BCC}$ list, but also those that fell just outside of the top 100. Although the total scores used to rank firms were not publicly available for firms that were excluded from the $100 \mathrm{BCC}$ list, we were able to obtain these scores directly from Sandra Waddock and Samuel Graves (Waddock et al., 2000), the two-primary academic researchers who had performed the ranking analysis for the magazine. Obtaining these data was necessary to understand which firms were similar to $100 \mathrm{BCC}$ members but barely missed the cutoff.

\section{Method}

To evaluate the investor response to CSR recognition, we adapt an empirically rigorous research design known as regression discontinuity (RD) to the analysis of stock returns in an event study (Cuñat, Gine, and Guadalupe, 2012; Flammer, 2015a). RD is a research design that is noted for its ability to produce reliable estimates of a causal relationship (Calonico et al., 2017) and is "often seen as the sharpest tool of causal inference since it approximates very closely the ideal setting of a randomized control experiment" (Flammer and Bansal, 2017: 1828).

Regression Discontinuity in the 100 BCC Ranking. The primary objective of this study is to estimate the relative effect of $100 \mathrm{BCC}$ inclusion on shareholder value on the announcement day for firm $i$. Each firm in the sample is rated using the KLD data and then ranked according to their overall score $S_{i}$. The overall score was computed by standardizing and adjusting the raw scores obtained from Business Ethics so that scores greater than or equal to zero indicate $100 \mathrm{BCC}$ inclusion. By definition, firms that are ranked 1 through 100 are included on the $100 \mathrm{BCC}$ list denoted by the indicator variable $B C C_{i}=1\left(S_{i} \geq S^{*}\right)$ where $S^{*}$ is threshold for inclusion. 
In an ideal world, the causal effect of $B C C_{i}$ would be estimated by randomly assigning inclusion. We use a RD design to approximate this idealized experiment. Central to any RD design is an assumption that firms just above or below a threshold are essentially the same. In this context, that threshold for treatment is a top 100 ranking. Assuming that firms that barely make the list (e.g. a ranking of 100) are similar to firms that were barely excluded (e.g. a ranking of 101), marginal inclusion on the $100 \mathrm{BCC}$ is thus akin to random assignment and can be used to test the causal impact of being recognized for CSR on subsequent shareholder value.

We first employ a nonparametric method that analyzes the difference in means between included and excluded firms in small bandwidths around the inclusion threshold. Following Flammer (2015a), we then use parametric estimation by employing the following RD specification to evaluate the causal effect of $100 \mathrm{BCC}$ inclusion

$$
y_{i}=\beta \times B C C_{i}+P_{l}\left(S_{i}, \gamma_{l}\right)+P_{r}\left(S_{i}, \gamma_{r}\right)+\varepsilon_{i}
$$

where $y_{i}$ is outcome variable of firm $i, \beta$ is the treatment effect of $100 \mathrm{BCC}$ inclusion, $P_{l}\left(S_{i}, \gamma_{l}\right)$ and $P_{r}\left(S_{i}, \gamma_{r}\right)$ are first-order polynomials on the left and right sides of the inclusion threshold used to control for differences among non-close firms. ${ }^{3}$

Event Study of the 100 BCC Ranking. We quantify the impact of marginal inclusion on firm value using an event study, a method developed to measure the effect of an unanticipated event on stock prices (McWilliams and Siegel, 1997). Like all event studies, we assume that financial markets are efficient which implies that stock prices incorporate all relevant information that is available to the market. If the market is efficient, novel information that was previously

\footnotetext{
${ }^{3}$ In the Appendix, we provide a brief description about the differences between nonparametric and parametric estimation. We also demonstrate that our results in parametric estimation are robust to alternative specifications using second- and third-order polynomials (Table A3).
} 
unanticipated should generate an abnormal return. We also assume that investors had access to the ranking once published and incorporated the information accordingly.

Knowledge of the initial $100 \mathrm{BCC}$ ranking was disseminated through a press release issued by Business Ethics magazine on PR Newswire on March 27, 2000 (Klusmann, 2000). Only the companies that made the list were published. The remaining firms that were evaluated but not included were therefore unknown to the public. We searched the Factiva and Lexis-Nexis databases and found no evidence that the ranking was introduced prior to the announcement date. This absence of evidence suggests that it was very unlikely that investors anticipated the initial publication and that the ranking therefore contained novel information.

Because the $100 \mathrm{BCC}$ ranking was determined using data from KLD that was previously available to investors, one could still question whether the ranking actually provided new information. While we acknowledge this concern, we also note that (1) prior research has shown that investors will respond to rankings as novel information even if the underlying data used to construct the ranking was already available (Lyon and Shimshack, 2015), (2) some investors were likely uninformed given that access to the underlying KLD data was not free (Brammer et al., 2009; Godfrey, 2011), and (3) even informed investors can revise their expectations about the future prospects of the company if they think that the information will be novel to other stakeholders (consumers, employees, etc.) (Brammer et al., 2009; Lyon and Shimshack, 2015). Given these factors, we believe that there is a strong likelihood that many investors would perceive the initial $100 \mathrm{BCC}$ list as novel and respond accordingly.

\section{Variable Definitions and Sample Characteristics}

Abnormal Return. We evaluate investor response to inclusion on the $100 \mathrm{BCC}$ list by computing the abnormal return on the announcement day (Flammer, 2015a). Using an abnormal 
return as the primary dependent variable of interest is appealing because it provides a direct estimate of the effect that $100 \mathrm{BCC}$ inclusion might have on firm value. Following prior research (Godfrey, Merrill, and Hansen, 2009; Madsen and Rodgers, 2015; McWilliams and Siegel, 1997), we compute abnormal returns using the market model which calculates expected returns by regressing a firm's daily stock return against a market portfolio over a period of time prior to the announcement day. As a robustness test, we also compute abnormal returns using the marketadjusted model and obtain substantively similar results. Consistent with prior work, we used a 255-day estimation window ending 46 days before the event and the CRSP value-weighted market portfolio.

\section{<Insert Table 1 here>}

Summary Statistics. Table 1 provides summary statistics for the abnormal return on the announcement day as well as other relevant firm characteristics commonly used to assess similarity between firms (Flammer, 2015a, 2015b). We construct an overall measure of corporate citizenship (KLD Index) by summing a firm's strengths and concerns along the following dimensions: customers, communities, the natural environment, minorities, and employees (Waddock et al., 2000). Total assets is the book value of assets. Market value is the number of shares outstanding multiplied by the stock price at the end of the fiscal year prior to announcement day. Return on Assets (ROA) is measured as the ratio of net income to book value of assets. Cash is the ratio of cash and short-term investments to total assets. Leverage is the ratio of debt in current liabilities and long-term debt to total assets. Institutional Ownership is the proportion of shares owned by institutional investors. Analyst Coverage is the number of unique analyst estimates in the I/B/E/S database in the prior year. DS 400 and DJSI are indicator variables equal to 1 if the firm was a member of the Domini Social 400 Index or the Dow Jones 
Sustainability Index respectively, and 0 otherwise. Finally, we use 4-digit SIC codes to identify firms whose customers are primarily other businesses (Srinivasan, Lilien, and Sridhar, 2011). Specifically, we create $B 2 B$ industry, an indicator variable equal to 1 if the company operates in a business-to-business (B2B) industry and 0 otherwise.

\section{Tests for Quasi-Randomized Assignment}

To test for quasi-random assignment, we evaluate (1) the continuity of BCC scores around the inclusion threshold and (2) the similarity of firms immediately in the treatment and control groups based on ex-ante characteristics.

Continuity in the Distribution of BCC Scores. We first examine whether the distribution of the overall score $S_{i}$ is continuous around the inclusion threshold. Discontinuities in the overall score around the threshold likely provide evidence of ratings manipulation which call into question the assumption of quasi-random assignment.

As shown in Figure A1 in the Appendix, the distribution of BCC scores appears normal and continuous around the inclusion threshold. We evaluate this condition more formally using the rddensity command, a STATA command introduced by Cattaneo et al. (2017) that tests for evidence of manipulation (i.e. discontinuity in the BCC score at the inclusion threshold). As can be seen in Figure A2 in the Appendix, we find no evidence to reject the null of a continuous distribution ( $\mathrm{p}$-value $=0.743$ ) thus supporting our assumption of a quasi-randomized treatment.

Preexisting differences. We also examine whether firms just above and below the inclusion threshold are similar on relevant ex-ante characteristics. We expect to find no significant differences among these firms if inclusion near the cutoff is indeed as good as random.

We test for significant differences among marginal firms using all of the aforementioned variables. We display the results of our tests in Table 2. To determine the optimal bin-width for analysis, we used the STATA command rdrobust and its companion command $r d b w s e l e c t$ (Calonico $e t$ 
al., 2017; Calonico, Cattaneo, and Titiunik, 2014). We found the optimal bin-width to be a window of +/20 ranks. Firms that fall within this range are what we consider "marginal" firms. We report an additional window of $+/-30$ ranks to demonstrate how bias can increase with increasing distance from the threshold. As shown in column (1), we find that firms that are included on the 100 BCC list differ significantly from companies that are excluded as one would expect. In column (2), we see that most of these differences become insignificant at a distance of 30 ranks, with the exception of membership on the DS 400 index. In column (3), we narrow the threshold to a distance of 20 ranks and discover no significant differences among marginally included or excluded firms. These results are consistent with the full sample RDD specification in column (4) that controls for distance from the threshold. As supporting evidence, we also plot each covariate against the overall BCC score and find no indication of significant discontinuities at threshold as shown in Figure A3 of the Appendix. Jointly, these results are consistent with our assumption that inclusion is approximately random and thus provide further support for our identification strategy.

<Insert Table 2 here>

\section{RESULTS}

\section{Main Results}

Graphical Analysis. To measure the impact of 100 BCC inclusion on shareholder value, we examine the stock market reaction on the day that the rankings were announced. Figure 1 provides a visualization of this impact. Specifically, the figure plots the abnormal returns against the overall BCC score. The solid vertical line represents the threshold for inclusion on the BCC list. Firms to the right of the inclusion threshold were included on the $100 \mathrm{BCC}$ while those to the left were excluded. Each dot represents the average abnormal return within an optimized bin- 
width on each side of the threshold. The solid lines plot predicted values of abnormal returns from first-order polynomials in the $100 \mathrm{BCC}$ score to the left and right of the inclusion threshold. $<$ Insert Figure 1 here>

Looking at the predicted values to the left of the threshold, we see that excluded firms do not appear to garner any significant investor response as one would expect given that on average, no news is being publicized about these firms that would lead to a significant abnormal return. To the right of the threshold, however, we see a positively sloping line suggesting that returns, relatively speaking, increase with higher $100 \mathrm{BCC}$ scores and thus higher rank. This result is entirely consistent with recent research that examines the relationship between rank and shareholder value (Lyon and Shimshack, 2015) and suggests that many investors found the ranking to contain novel information, despite being based on data that was previously available to the public. The most interesting aspect of the graph, however, is the discontinuous drop at the inclusion threshold. Indeed, this drop suggests that firms that just barely make the list experience a decrease in firm value compared to firms that just miss the cutoff.

Regression Analysis. The graphical analysis in Figure 1 suggests that inclusion on the 100 $\mathrm{BCC}$ list leads to a decrease in shareholder value for marginal firms. We provide a formal test of this claim in Table 3 using both nonparametric and parametric estimation.

<Insert Table 3 here>

We first report our results using nonparametric estimation which computes estimates of the difference in abnormal returns between firms that are included and excluded for increasingly small intervals around the inclusion threshold. In column (1) of Table 3, we examine the full sample of 513 firms. Consistent with prior work, we find a negative but insignificant effect for 100 BCC inclusion (Brammer et al., 2009). Column (2) restricts the sample to non-close firms, 
that is, firms that were more than 30 ranks from the inclusion threshold. Again, the results show no discernable difference in abnormal returns between the included and excluded firms, likely because this subsample is largely composed of excluded firms for whom one would not expect a market response.

In columns (3) through (4), we restrict the sample to increasingly smaller bin widths around the inclusion threshold. We use the STATA command rdrobust to compute nonparametric estimates with triangular kernels that put greater weight on firms closer to the threshold (Calonico et al., 2017; Calonico et al., 2014; Tian, Smith, and King, 2019). For firms within 30 ranks of the inclusion threshold, we find that the difference in abnormal returns is $-2.2 \%(\mathrm{p}=$ 0.007). For firms within 20 ranks, the optimal bin-width, we see the difference between included and excluded firm increases in magnitude to $-2.7 \%(\mathrm{p}=0.007)$. Overall, the results displayed in columns (3) - (4) indicate that firms who barely make the 100 BCC list experience a significant decrease in shareholder value compared to firms that barely miss the cut.

We also report our results using parametric estimates in Table 3. In column (5), we run our primary RD regression that controls for the distance from the inclusion threshold using firstorder polynomials. Unlike the nonparametric estimates listed in columns (3) through (4), this model incorporates the full sample of firms $(\mathrm{N}=513)$ and thus provides a more efficient and precise estimate of the causal effect of marginal inclusion on abnormal returns. Similar to the nonparametric results in columns (3) and (4), we find a statistically significant $-1.3 \%$ difference between included and excluded firms, even after controlling for distance from the inclusion threshold. Although this magnitude may seem small, we found it to be consistent with other events studies that examine investor responses to CSR-related information (Flammer, 2015a; Flammer and Bansal, 2017). Taken together, these results provide strong evidence that inclusion 
on the $100 \mathrm{BCC}$ list leads to a decrease in firm value for marginal firms. In the Appendix, we demonstrate that this finding is robust to a number of additional sensitivity tests.

\section{Moderating Effects: CSR Specificity, Consistency, and Relevancy}

Our initial results suggest that marginal inclusion on the $100 \mathrm{BCC}$ list can be detrimental to firm value. We suspect, however, that investor reactions to a ranked list may also be moderated by other salient firm characteristics that are not captured by the ranking, namely a firm's prior reputation (Kim and King, 2014). Prior research, for example, suggests that firms that engage in predictable patterns of organizational outcomes and behaviors that are relevant to specific audience interests become "known for something" (Jensen, Kim, and Kim, 2012; Lange, Lee, and Dai, 2011) which helps to establish a domain-specific reputation among key stakeholders (Carlos and Lewis, 2018; McDonnell and King, 2018). Such a reputation could enhance firm value by leading to increased revenues (Lev, Petrovits, and Radhakrishnan, 2010) or reduced capital costs (Cheng, Ioannou, and Serafeim, 2014) or a preservation of firm's value when experiencing a negative event (Flammer, 2013; Godfrey et al., 2009; Luo, Kaul, and Seo, 2018), all outcomes valued by investors (Fombrun, 1996; Pfarrer, Pollock, and Rindova, 2010; Rhee and Haunschild, 2006). Because investors may be more willing to accept a firm's CSR investments if the connection between the investment and some valued outcome such as reputation is more salient, we suspect that marginally included firms with strong reputations for CSR may be less likely to be devalued when barely making the 100 BCC list.

Accordingly, we examine three antecedents to a socially responsible reputation that may explain investors' varying responses, namely the specificity, consistency, and relevance of a firm's CSR investments (Lange et al., 2011). First, we expect that firms that make concentrated or focused investments in specific dimensions of CSR are more likely to generate a domain- 
specific reputation for CSR relative to other firms that engage in more general or diverse behaviors (Carlos and Lewis, 2018; Jensen et al., 2012). Second, we anticipate that an established history of consistent socially responsible behavior is more likely to be perceived as genuine by stakeholders which may lead to higher levels of reputational capital amongst investors (Barnett, 2007; Godfrey, 2005). Third, we predict that engaging in activities that are relevant and viewed as material by key stakeholders can help to strengthen a company's reputation amongst that audience (Khan, Serafeim, and Yoon, 2016; Rindova and Martins, 2012). Collectively, we suspect that these three factors represent antecedents of a socially responsible reputation that are likely to attenuate the negative investor response to marginally included firms.

We examine each of these moderating effects in Panel B of Table 3. We first evaluate the moderating impact of investing in specific or focused dimensions of CSR. To operationalize this variable, we compute the standard deviation of ratings among the four stakeholder groups evaluated by the BCC list: community, employees, customers, and shareholders. Firms that have concentrated their investments in one particular domain are likely to have a higher standard deviation than firms whose investments were spread more equally (see the Appendix for an example). We then split the full sample into two based on a median split of the standard deviation score for 100 BCC firms. As displayed in columns (1) and (2), the negative effect of inclusion appears to affect only firms whose CSR investments are less specific (i.e. more general). Marginal firms that have focused CSR investments appear to be less likely to experience decreases in firm value, perhaps because they develop domain-specific reputations (Carlos and Lewis, 2018; McDonnell and King, 2018), which may be more salient to investors. 
We then examine the impact of a prior history of investments in CSR. To evaluate this history, we compute the change in the KLD index between 1999 (t-1) and $1996(\mathrm{t}-4)$. We then classify firms into two groups: (1) those whose change in the KLD index was greater than 0 (No History of CSR) and (2) those whose change in the KLD index was less than or equal to 0 (History of CSR). Firms with significantly positive differences are not likely to have a wellestablished history of CSR investments (see the Appendix for an example). Based on the results from columns (3) and (4), it appears that the negative effect of inclusion for marginal firms does indeed only apply to those firms who lack a strong historical record of CSR investments. Conversely, marginal firms that do have a relatively strong history of CSR investments appear to be somewhat protected from the decrease in firm value, likely because consistent investments over time are more likely to be perceived as credible (Barnett, 2007; Barnett and Salomon, 2012) and thus generate more reputational capital (Godfrey, 2005).

Finally, we investigate the effect of making relevant or material investments in CSR for marginal firms. Following recent work by Khan and colleagues (2016), we utilize guidance from the Sustainability Accounting Standards Board (SASB) to identify material sustainability issues for companies within the same industry and then map these material issues to the KLD ratings (see the Appendix for more details). We then compute the ratio of material strengths enacted by the firm to the number of material strengths assigned to the firm's industry. Firms with positive proportions (i.e. those that are making investments in material issues) are deemed as having a higher level of material CSR investment while firms with a proportion equal to zero are deemed as making no material CSR investment. As shown in columns (5) and (6), a negative investor response to marginal inclusion seems to apply to firms that do not invest in material CSR initiatives. On the other hand, marginal firms that make material CSR seem to be buffered from a 
decrease in firm value, arguably because targeting initiatives that match investors' interests helps to build their reputation among shareholders (Khan et al., 2016; Lange et al., 2011).

\section{External Validity}

Although the RD design employed in this study is advantageous for identifying the causal effect of being marginally included on the 100 BCC list, our analysis may be limited in generalizability given that the effect is identified by a small subset of firms around the inclusion threshold that, while being similar to each other, may be very different from firms farther away from the threshold. Likewise, the companies in the $100 \mathrm{BCC}$ evaluation universe may not be representative of the broader population of public firms from which they are drawn. To address these concerns, we evaluate (1) whether companies around the inclusion threshold differ systematically from companies that are farther away and (2) whether the sample of BCC evaluated firms differs significantly from the broader population of public corporations. We display the results of these comparisons in Table A10 of the Appendix.

We find that firms near the inclusion threshold have significantly higher levels of corporate citizenship as measured by the KLD index, are more profitable, and are also more likely to be members of the DS 400 index. This result, while interesting, is not surprising given that (1) the 100 BCC ranking, by construction, selects approximately the top $20 \%$ of firms in terms of corporate citizenship and shareholder return and (2) the DS 400 is a compilation of socially responsible companies as determined by KLD (Godfrey, 2011; Waddock et al., 2000). Taken together, these comparisons suggest that marginal firms near the inclusion threshold may not necessarily be representative of the broader population from which they were selected (i.e. S\&P 500 firms). They do, however, suggest that barely making a list may be detrimental to shareholder value, but only for companies that appear to be actively investing in the dimension 
of performance that is being ranked. We also find firms evaluated for inclusion on the $100 \mathrm{BCC}$ to be significantly different from the broader population of public firms. Indeed, firms in the 100 BCC universe are much larger, more profitable, and more likely to be tracked by analysts and institutional investors. Although these differences do not bias our estimate of the treatment effect of marginal inclusion, they do suggest that our findings may not apply to the typical US public firm.

\section{DISCUSSION AND CONCLUSION}

Firms face important strategic decisions about how to manage their resources and attention in pursuing rankings. Although prior theory generally assumes that rankings bestow disproportionate benefits to ranked actors (Merton, 1968), empirical support for this causal relationship is limited. Through our access to a unique dataset and implementation of a novel empirical design, we found surprising empirical evidence that departs from prevailing theoretical expectations.

\section{Empirical findings}

Utilizing a regression discontinuity design, we examined the effect of marginal inclusion on the 100 Best Corporate Citizen's list on shareholder value. Our primary results indicate that firms that were marginally included on the 100 Best Corporate Citizen's list experienced a 1.3\% decrease in firm value compared to firms that were marginally excluded. We also sought to understand the materiality of these results by interpreting the estimated decrease in absolute terms. Given that the median marginal firm (those within 20 ranks of the inclusion threshold) had a market value that ranged from $\$ 805$ million $\left(10^{\text {th }}\right.$ percentile) to $\$ 32$ billion ( $90^{\text {th }}$ percentile), the estimated effect of marginal inclusion of $-1.3 \%$ would translate to an expected decrease ranging from $\$ 10$ million to $\$ 416$ million in market value, with a median estimate of $\$ 83$ million. 
From an empirical perspective, our study highlights a potential opportunity for scholars who study investor responses to rankings and lists. Although many academics have sought to understand the financial consequences of being included on prestigious lists (Brammer et al., 2009; Edmans, 2011; Fulmer et al., 2003; Jones and Murrell, 2001; Lyon and Shimshack, 2015), most of these studies, "do not compare abnormal returns of similar firms that are not on the index" (Hawn et al., 2018: 950) and are thus limited in their ability to estimate the causal consequences of inclusion (Flammer, 2015a). Recent studies have sought to address this limitation by using matching methods to construct a comparable group of control firms (Durand, Paugam, and Stolowy, 2019; Hawn et al., 2018) but even these studies cannot estimate a true causal relationship because they lack knowledge about which firms apply but are rejected.

We address this limitation by collecting the underlying performance data for all firms that were evaluated for the $100 \mathrm{BCC}$, even those that fell outside of the top 100 ranked firms. Indeed, this unique access to data is what enabled us to estimate the causal relationship of $100 \mathrm{BCC}$ inclusion. While access to proprietary data will always be a challenge, many ranking agencies (e.g. Business Ethics) base their evaluations on public information that is already available (e.g. KLD). Often all that is needed to reconstruct the ranking for the full population of evaluated firms is a more in-depth explanation of the third-party's ranking methodology. We thus encourage scholars who study rankings and lists, whenever possible, to seek out information on the ranked but unpublished organizations. Doing so will allow future research to employ rigorous research designs to estimate causal relationships (Flammer, 2015a; Hawn et al., 2018; Lev et al., 2010), thus expanding our empirical knowledge about the consequences of being ranked.

\section{Theoretical implications}


Rankings and Status. Our empirical findings represent a surprising departure from prior theoretical expectations dating back to Merton's conceptualization of the $41^{\text {st }}$ chair. Using the example of the French Academy and its limit of only recognizing the top 40 scientists in the field, Robert Merton identified the $41^{\text {st }}$ chair as "an artifact of having a fixed number of places available at the summit of recognition" (1968:2). As he explains, despite generally indiscernible differences in talent and quality of research, scientists that occupy the $40^{\text {th }}$ chair receive incommensurate career-propelling benefits compared with peers who were not recognized by the Academy and thus relegated to the $41^{\text {st }}$ chair.

Although our focus was on the empirical phenomenon, our findings point to an important theoretical dimension not considered by Merton's $41^{\text {st }}$ chair analogy, namely the potential for a liability of comparison that may arise from gaining inclusion in a prominent category. By grouping together ranked firms into a comparison set, rankings may restructure how firms are evaluated by focusing audience attention to the comparison of a given firm with the other ranked firms on the list (Bowers, 2015). As our results suggest, these categorical comparisons may be detrimental for lower-ranked firms by enhancing the salience of the performance disparity with higher ranked firms. We see this counterintuitive findin as providing further evidence of the limits and potential downsides of status (Azoulay et al., 2014; Graffin et al., 2013; Reschke et al., 2017) and as further motivation to study the implications of competition near status boundaries (Otner, 2018; Piezunka et al., 2018).

Our results also build directly on recent research that examines how status gains and losses can occur as a result of structural changes in categories. When status shifts are independent of substantive changes in firm performance, they are referred to as "unearned" (Bowers and Prato, 2018; Neeley and Dumas, 2016). Although prior research has investigated the impacts of these 
changes on firm outcomes (Bowers and Prato, 2018) and has considered how individuals respond to experiencing unearned status gains and losses (Neeley and Dumas, 2016), our study may help to delineate new boundary conditions regarding how audiences interpret and respond to unearned status gains (George et al., 2016). Consistent with prior research, our results indicate that highly ranked firms seem to benefit from structural changes that bestow status. However, unlike prior work, we note that, at the margin, unearned status may represent a liability. Our moderators help unpack this relationship by indicating that firms that had strong CSR reputations were buffered from these liabilities. In other words, firms with a prior reputation for CSR were likely viewed as having "earned" their status gains, compared with those at the margin lacking a reputation for CSR. From these findings, we surmise that at the margins unearned status gains or losses may be more likely to be detected by audiences.

Finally, our results contribute to recent conversations regarding the potential liabilities associated with positive recognition. For example, Kovacs and Sharkey (2014) show that the ratings of award-winning books tend to decline after those books receive an esteemed award, primarily because awards broaden the audience for books and in so doing attract more diverse readers with different tastes. Similar to this research, we find potential negative implications of awards in the form of rankings. However, our results highlight a potential alternative mechanism. While Kovacs and Sharkey (2014) link negative outcomes to audience expansion, our findings suggest that rankings may create a liability of comparison by emphasizing the relative performance disparity between low and high ranked firms.

Strategic CSR. Our study also speaks to the ongoing conversation regarding the strategic value of CSR investments. Using a similar research design to our own, recent work has found a positive causal relationship between CSR and firm value (Flammer, 2015a; Flammer and Bansal, 
2017). Although our results may seem to contradict these previous findings, we believe they differ in important ways and are thus complementary, not contradictory.

First, we believe these studies differ in their treatments. For example, Flammer and colleagues examine investor response to the approval and implementation of CSR-related shareholder proposals (2015a; 2017). Our study, however, focuses on investor response to recognition of CSR by a third-party. Because we use similar research designs, we suspect that these different findings are likely a result of the treatment itself: implementation vs. recognition. Second, we also note that the ratings used to construct the $100 \mathrm{BCC}$ list in the inaugural year (2000) were based on KLD data that was already publicly available (1996-1998) (Brammer et al., 2009). Given this observation, if all investors cared about was the implementation of CSR initiatives, it would be unlikely that we would observe any substantive change in firms' stock prices on the day of the $100 \mathrm{BCC}$ announcement given that the performance information underlying the ranking (i.e. the KLD ratings) was already available. The fact that we see any response at all is thus further evidence that the $100 \mathrm{BCC}$ recognition changed investors' perceptions about the present value of the firm independent of what had already been approved and implemented by the firm (Lyon and Shimshack, 2015).

Taken together, we believe these studies jointly highlight an important conceptual distinction between CSR implementation and CSR recognition, a difference that has often been overlooked in the literature, perhaps due to assumptions that firms that engage in socially responsible initiatives will naturally want to publicize and therefore be recognized for their efforts (Carlos and Lewis, 2018; Delmas and Grant, 2014). While prior work has found shareholders do value the approval and implementation of CSR initiatives (Flammer, 2015a; Flammer and Bansal, 2017), based on our results, it appears that that shareholders may also punish firms that fail to 
gain a certain level of recognition or notoriety for their CSR investments. Given these findings, we thus encourage scholars who study the strategic value of CSR to consider whether their empirical observation of CSR is an implementation event or a recognition event and how and why this distinction might lead differing performance results.

\section{Strategic implications for managers}

Our primary empirical result suggests that firms that were barely included on the $100 \mathrm{BCC}$ list experienced a decrease in firm value when the list was announced. Theoretically, we suggest that these negative effects may stem from a liability of comparison, whereby performance discrepancies between marginally ranked and top ranked firms are amplified. In the case of a new non-voluntary ranking, firms may have little control over the set of organizations to which they are compared. However, our results suggest that one viable strategy to buffer firms from the risk of a marginal ranking is to establish a strong reputation by engaging in focused and consistent activities that are relevant to the interests of their primary stakeholders (Lange et al., 2011).

Indeed, our moderating analysis revealed that marginal firms were immune to negative investor perceptions when they were known for something specific (Lange et al., 2011), had pattern or history of consistent investments (Barnett, 2007; Godfrey, 2005), and when they focused on investments that were relevant and impactful (i.e. material) in the eyes of shareholders (Khan et al., 2016; Rindova and Martins, 2012). Taken together, these results provide three key takeaways for managers who desire to compete for a spot on a ranked list but wish to avoid possible liabilities of marginal inclusion. First, building a domain-specific reputation (Carlos and Lewis, 2018; McDonnell and King, 2018) may be a good initial strategy to buffer firms from the potential liability of a low ranking, at least until they acquire sufficient 
resources and capabilities to broaden the dimensions upon which their reputation is based.

Second, given the value of consistency (Barnett and Salomon, 2012; Hawn et al., 2018), mangers should ensure that their firm provides sufficient resources to sustain investments in the evaluated activities over time. Third, managers should become attuned to the needs and interests of different stakeholders (Hiatt and Carlos, 2019; Hiatt, Carlos, and Sine, 2018) and consider whether their investments actually make a material difference.

Managers may also wish to reexamine their firms' commitment to being ranked. While our primary analysis focused on the negative effects of marginal inclusion, our findings do seem to suggest that being ranked near the top of a list could be beneficial, or at least not harmful (see Figure 1). Given these results, firms that desire to compete for a spot on a particular ranking may wish to continue making investments that result in a rank that facilitates favorable comparisons among listed entities. Conversely, firms that have little ability or desire to compete may wish to redirect their investments to avoid being ranked or perhaps elect not to participate in the ranking altogether. After all, firms that are lukewarm in their efforts to manage their ranking may find themselves "stuck in the middle" and subsequently discounted by investors who perceive them to be bearing the costs of pursuing a ranking without enjoying the benefits (Barnett and Salomon, 2006: 1119).

\section{A Research Agenda: Rankings and the Impact of Marginal Inclusion}

Although we are confident in the robustness of our results within the confines of this particular context, we cannot conclusively ascertain whether or when similar liabilities for marginally ranked firms would generalize to other rankings. For example, our study focused on a particular type of ranking (non-voluntary) with one dimension of performance (corporate citizenship) and a finite number of ranks (100). We also evaluated reactions to marginal 
inclusion by one audience (investors) at one particular point in time in history (the year 2000 and the first year of the ranking). Given such specificity, one could indeed question whether marginal inclusion on a ranking with differing elements would generate a similar effect.

Fortunately, given the proliferation of rankings in recent years (Fombrun, 2007), we suspect there are a number of promising research contexts in which differing structural elements of a ranking could be examined in order to determine whether this effect generalizes beyond the current context. For example, future studies could examine how marginally ranked universities compare to the unranked on outcomes such as alumni donations, applications, placement, etc. (Elsbach and Kramer, 1996; Espeland and Sauder, 2007). Other promising contexts to examine may include other general firm reputation rankings (Bermiss, Zajac, and King, 2014), the ranking of hospitals (Pope, 2009), books (Kovács and Sharkey, 2014), hotels (Orlikowski and Scott, 2014), restaurants (Luca and Zervas, 2016), and automobiles (Rao, 1994). Consequently, despite limitations in generalizability, we believe this study provides a strong foundation upon which future research can build in order to understand the reach and limits of our primary empirical finding. We explore several of these areas of inquiry below.

Ranking Characteristics. First, we suspect that variation in ranking characteristics could impact the generalizability of our results. For example, one particular aspect of the $100 \mathrm{BCC}$ list was that firms did not voluntarily apply for inclusion but were rather evaluated and ranked based on publicly available data. Although other rankings likewise evaluate actors without their approval, it is also common for firms to apply for inclusion on a ranking by filling out extensive questionnaires (Carlos and Lewis, 2018; Dineen and Allen, 2016), particularly if they already excel on the dimension of performance being ranked. Because we find that a prior reputation can attenuate the negative effect of marginal inclusion, these differences in selection raise questions 
about whether similar findings would extend to rankings that are based on voluntary applications. One could also consider whether similar findings would apply to other ranked dimensions of performance. CSR, for example, has historically been viewed as subordinate to the core functions of the business. Rankings associated with activities more directly connected to core business operations, such as quality and innovation, could conceivably produce different results. Future research could therefore examine whether a liability of comparison generalizes to other ranked dimensions of performance. Last but not least, the number of available spaces on a ranked-list could impact the prevalence of this negative effect. In this study, that number was 100. Smaller lists (e.g. Top 10, or Top 20 ranking) however, could attenuate the effect as the relative distance between a top- and bottom-ranked firm declines. Given the varying means of solicitation, ranked performance dimensions, and sizes of ranked lists, future research could examine whether each of these factors amplify or attenuate the negative effect of marginal inclusion.

Audience Characteristics. Second, our study focused on investor response to marginal inclusion, but there are indeed many other audiences influenced by rankings. Investors, for instance, primarily consider how information conveyed by rankings is likely to impact future financial returns. Given that all companies would be evaluated on the same dimension, investors may treat individual firms like commodities that only differ in terms of their potential future return. In contrast, individual customers may care more about specific products and brands which could reduce the number of firms within their consideration set and thus decrease the relative distance between top-ranked and marginally ranked actors. Future research could thus examine whether the motives and interests of other key stakeholders (i.e. customers, employees, media, etc.) moderate the negative effect of marginal inclusion. 
Historical Attributes. Third, our study evaluated a ranking within a particular time in history, both the history of the ranking itself and the history of the performance dimension being ranked. For example, our analysis of the $100 \mathrm{BCC}$ focused on investor responses during the inaugural year. These findings thus represent responses to a new ranking that represent structural changes in categories that give new meaning to existing performance metrics. Accordingly, we suspect that similar results may be found in situations where the ranking provides novel information to external audiences, either through the creation of a new ranking system or through significant changes to existing ranking systems that re-categorize criteria in unanticipated ways. In addition, our analysis was also performed during a time period in which CSR, the dimension of performance being ranked, was still becoming institutionalized (Carlos and Lewis, 2018; Flammer, 2013; Ioannou and Serafeim, 2015; Marquis, Glynn, and Davis, 2007). Consequently, our findings regarding the negative effects of marginal inclusion could be partially explained by lack of knowledge and understanding among investors regarding the economic benefits of CSR investments. For example, one might expect that decreases in firm value could very well be attenuated by increased acceptance of CSR as a legitimate strategic function. While we are unable to test this notion using the same context given that it is historically fixed in time, future research could examine how external audience members respond to rankings over time when the dimension of performance being ranked becomes perceived as more legitimate (Hawn et al., 2018; Ioannou and Serafeim, 2015).

\section{Conclusion}

In summary, we believe our study presents important implications for how ratings may impact firm performance. Our core finding is that firms at the margin may actually be penalized rather than rewarded for inclusion on a prestigious ranking. However, we also find that these 
effects may be attenuated by individual firm characteristics reflected in a firm's reputation within the same domain the ranking. These results provide provocative new insights into taken for granted assumptions about the value of receiving positive social evaluations such as rankings, certifications, or awards. Given the increasing prevalence of these forms of recognition, we believe additional research in this area is imperative and hope that our findings will inspire future research that helps to bring forth new insights into this important topic.

\section{REFERENCES}

Azoulay P, Stuart T, Wang Y. 2014. Matthew: Effect or fable? Management Science 60(1): 92109.

Barnett ML. 2007. Stakeholder influence capacity and the variability of financial returns to corporate social responsibility. Academy of Management Review 32(3): 794-816.

Barnett ML, Salomon RM. 2006. Beyond dichotomy: The curvilinear relationship between social responsibility and financial performance. Strategic Management Journal 27(11): 11011122.

Barnett ML, Salomon RM. 2012. Does it pay to be really good? Addressing the shape of the relationship between social and financial performance. Strategic Management Journal 33(11): 1304-1320.

Bermiss YS, Zajac EJ, King BG. 2014. Under construction: How commensuration and management fashion affect corporate reputation rankings. Organization Science 25(2): 591-608.

Bowers A. 2015. Relative comparison and category membership: The case of equity analysts. Organization Science 26(2): 571-583.

Bowers A, Prato M. 2018. The structural origins of unearned status: How arbitrary changes in categories affect status position and market impact. Administrative Science Quarterly 0(0): 0001839217727706.

Brammer S, Brooks C, Pavelin S. 2009. The stock performance of America's 100 Best Corporate Citizens. The Quarterly Review of Economics and Finance 49(3): 1065-1080.

Calonico S, Cattaneo MD, Farrell MH, Titiunik R. 2017. rdrobust: Software for regressiondiscontinuity designs. Stata Journal 17(2): 372-404.

Calonico S, Cattaneo MD, Titiunik R. 2014. Robust data-driven inference in the regressiondiscontinuity design. Stata Journal 14(4): 909-946.

Calonico S, Cattaneo MD, Titiunik R. 2015. Optimal data-driven regression discontinuity plots. Journal of the American Statistical Association 110(512): 1753-1769.

Carlos WC, Lewis BW. 2018. Strategic silence: Withholding certification status as a hypocrisy avoidance tactic. Administrative Science Quarterly 63(1): 130-169.

Cattaneo MD, Jansson M, Ma X. 2017. rddensity: Manipulation testing based on density discontinuity. STATA Journal: Forthcoming.

Chatterji AK, Toffel MW. 2010. How firms respond to being rated. Strategic Management Journal 31(9): 917-945. 
Cheng B, Ioannou I, Serafeim G. 2014. Corporate social responsibility and access to finance. Strategic Management Journal 35(1): 1-23.

Cuñat V, Gine M, Guadalupe M. 2012. The vote is cast: The effect of corporate governance on shareholder value. The Journal of Finance 67(5): 1943-1977.

Delmas MA, Grant LE. 2014. Eco-labeling strategies and price-premium: The wine industry puzzle. Business \& Society 53(1): 6-44.

Dineen BR, Allen DG. 2016. Third party employment branding: Human capital inflows and outflows following "Best Places to Work" certifications. Academy of Management Journal 59(1): 90-112.

Durand R, Paugam L, Stolowy H. 2019. Do investors actually value sustainability indices? Replication, development, and new evidence on CSR visibility. Strategic Management Journal.

Edmans A. 2011. Does the stock market fully value intangibles? Employee satisfaction and equity prices. Journal of Financial Economics 101(3): 621-640.

Elsbach KD, Kramer RM. 1996. Members' responses to organizational identity threats: Encountering and countering the Business Week rankings. Administrative Science Quarterly 41(3): 442-476.

Espeland WN, Sauder M. 2007. Rankings and reactivity: How public measures recreate social worlds. American Journal of Sociology 113(1): 1-40.

Espeland WN, Sauder M. 2016. Engines of anxiety: Academic rankings, reputation, and accountability. Russell Sage Foundation.

Espeland WN, Stevens ML. 1998. Commensuration as a social process. Annual Review of Sociology 24(1): 313-343.

Flammer C. 2013. Corporate social responsibility and shareholder reaction: The environmental awareness of investors. Academy of Management Journal 56(3): 758-781.

Flammer C. 2015a. Does corporate social responsibility lead to superior financial performance? A regression discontinuity approach. Management Science 61(11): 2549-2568.

Flammer C. 2015b. Does product market competition foster corporate social responsibility? Evidence from trade liberalization. Strategic Management Journal 36(10): 1469-1485.

Flammer C, Bansal P. 2017. Does a long-term orientation create value? Evidence from a regression discontinuity. Strategic Management Journal 38(9): 1827-1847.

Fombrun CJ. 1996. Reputation: Realizing Value From The Corporate Image. Harvard Business School Press: Boston, MA.

Fombrun CJ. 2007. List of lists: A compilation of international corporate reputation ratings. Corporate Reputation Review 10(2): 144-153.

Fulmer IS, Gerhart B, Scott KS. 2003. Are the 100 Best better? An empirical investigation of the relationship between being a "Great Place to Work" and firm performance. Personnel Psychology 56(4): 965-993.

George G, Dahlander L, Graffin SD, Sim S. 2016. Reputation and status: Expanding the role of social evaluations in management research. Academy of Management Journal 59(1): 113.

Godfrey PC. 2005. The relationship between corporate philanthropy and shareholder wealth: A risk management perspective. Academy of Management Review 30(4): 777-798.

Godfrey PC. 2011. Kinder, Lydenberg, and Domini (KLD) and socially responsible investing, William Davidson Institute: University of Michigan. 
Godfrey PC, Merrill CB, Hansen JM. 2009. The relationship between corporate social responsibility and shareholder value: An empirical test of the risk management hypothesis. Strategic Management Journal 30(4): 425-445.

Graffin SD, Bundy J, Porac JF, Wade JB, Quinn DP. 2013. Falls from grace and the hazards of high status: The 2009 British MP expense scandal and its impact on parliamentary elites. Administrative Science Quarterly 58(3): 313-345.

Graffin SD, Ward AJ. 2010. Certifications and reputation: Determining the standard of desirability amidst uncertainty. Organization Science 21(2): 331-346.

Gunther M. 2010. CRO awards spotlight what's wrong with awards. https://www.greenbiz.com/blog/2010/03/24/cro-awards-spotlight-whats-wrong-awards (December 21, 2017).

Hawn O, Chatterji AK, Mitchell W. 2018. Do investors actually value sustainability? New evidence from investor reactions to the Dow Jones Sustainability Index (DJSI). Strategic Management Journal 39(4): 949-976.

Hendricks KB, Singhal VR. 1996. Quality awards and the market value of the firm: An empirical investigation. Management Science 42(3): 415-436.

Hiatt SR, Carlos WC. 2019. From farms to fuel tanks: Stakeholder framing contests and entrepreneurship in the emergent U.S. biodiesel market. Strategic Management Journal 40(6): 865-893.

Hiatt SR, Carlos WC, Sine WD. 2018. Manu Militari: The institutional contingencies of stakeholder relationships on entrepreneurial performance. Organization Science 29(4): 633-652.

Ioannou I, Serafeim G. 2015. The impact of corporate social responsibility on investment recommendations: Analysts' perceptions and shifting institutional logics. Strategic Management Journal 36(7): 1053-1081.

Jensen M, Kim H, Kim BK. 2012. Meeting expectations: A role-theoretic perspective on reputation. In The Oxford Handbook of Corporate Reputation. Pollock T, G., Barnett ML (eds.), Oxford University Press: Oxford.

Jones R, Murrell AJ. 2001. Signaling positive corporate social performance: An event study of family-friendly firms. Business \& Society 40(1): 59-78.

Khan M, Serafeim G, Yoon A. 2016. Corporate sustainability: First evidence on materiality. The Accounting Review 91(6): 1697-1724.

Kim JW, King BG. 2014. Seeing stars: Matthew effects and status bias in Major League Baseball umpiring. Management Science 60(11): 2619-2644.

Klassen RD, McLaughlin CP. 1996. The impact of environmental management on firm performance. Management Science 42(8): 1199-1214.

Klusmann T. 2000. Business Ethics magazine publishes list of 100 Best Corporate Citizens: Celebrating those companies that excel at serving multiple stakeholders well. https://web.archive.org/web/20000817222423/http:/www.businessethics.com:80/the100.htm\#100\%20Best\%20Story.

Kovács B, Sharkey AJ. 2014. The paradox of publicity: How awards can negatively affect the evaluation of quality. Administrative Science Quarterly 59(1): 1-33.

Lange D, Lee PM, Dai Y. 2011. Organizational reputation: A review. Journal of Management 37(1): 153-184.

Leclerc F, Hsee CK, Nunes JC. 2005. Narrow focusing: Why the relative position of a good in its category matters more than it should. Marketing Science 24(2): 194-205. 
Lee BH, Hiatt SR, Lounsbury M. 2017. Market mediators and the trade-offs of legitimacyseeking behaviors in a nascent category. Organization Science 28(3): 447-470.

Lee DS, Lemieux T. 2010. Regression discontinuity designs in economics. Journal of Economic Literature 48(2): 281-355.

Lev B, Petrovits C, Radhakrishnan S. 2010. Is doing good good for you? How corporate charitable contributions enhance revenue growth. Strategic Management Journal 31(2): 182-200.

Lewis BW. 2017. The paradox of recognizing responsibility: Social ratings, philanthropy, and the market for virtue. Academy of Management Proceedings 2017(1).

Lewis BW, Walls JL, Dowell GWS. 2014. Difference in degrees: CEO characteristics and firm environmental disclosure. Strategic Management Journal 35(5): 712-722.

Luca M, Zervas G. 2016. Fake It till you make It: Reputation, competition, and Yelp review fraud. Management Science 62(12): 3412-3427.

Luo J, Kaul A, Seo H. 2018. Winning us with trifles: Adverse selection in the use of philanthropy as insurance. Strategic Management Journal 39(10): 2591-2617.

Lyon TP, Shimshack JP. 2015. Environmental disclosure: Evidence from Newsweek's Green Companies Rankings. Business \& Society 54(5): 632-675.

Madsen PM, Rodgers ZJ. 2015. Looking good by doing good: The antecedents and consequences of stakeholder attention to corporate disaster relief. Strategic Management Journal 36(5): 776-794.

Marquis C, Glynn MA, Davis GF. 2007. Community isomorphism and corporate social action. Academy of Management Review 32(3): 925-945.

McDonnell M-H, King BG. 2018. Order in the court: How firm status and reputation shape the outcomes of employment discrimination suits. American Sociological Review 83(1): 6187.

McWilliams A, Siegel D. 1997. Event studies in management research: Theoretical and empirical issues. Academy of Management Journal 40(3): 626-657.

Merton RK. 1968. The Matthew effect in science. Science 159(3810): 56-63.

Neeley TB, Dumas TL. 2016. Unearned status gain: Evidence from a global language mandate. Academy of Management Journal 59(1): 14-43.

Orlikowski WJ, Scott SV. 2014. What happens when evaluation goes online? Exploring apparatuses of valuation in the travel sector. Organization Science 25(3): 868-891.

Otner SMG. 2018. Near-winners in status competitions: Neglected sources of dynamism in the Matthew effect. Journal of Management Inquiry 27(4): 374-377.

Pfarrer MD, Pollock TG, Rindova VP. 2010. A tale of two assets: The effects of firm reputation and celebrity on earnings surprises and investors' reactions. Academy of Management Journal 53(5): 1131-1152.

Piezunka H, Lee W, Haynes R, Bothner MS. 2018. The Matthew effect as an unjust competitive advantage: Implications for competition near status boundaries. Journal of Management Inquiry 27(4): 378-381.

Podolny JM. 2010. Status signals: A sociological study of market competition. Princeton University Press.

Pope DG. 2009. Reacting to rankings: Evidence from “America's Best Hospitals". Journal of Health Economics 28(6): 1154-1165. 
Rao H. 1994. The social construction of reputation: Certification contests, legitimation, and the survival of organizations in the American automobile industry: 1895-1912. Strategic Management Journal 15(S1): 29-44.

Reschke BP, Azoulay P, Stuart TE. 2017. Status spillovers: The effect of status-conferring prizes on the allocation of attention. Administrative Science Quarterly: Forthcoming.

Rhee M, Haunschild PR. 2006. The liability of good reputation: A study of product recalls in the U.S. automobile industry. Organization Science 17(1): 101-117.

Rindova VP, Martins LL. 2012. Show me the money: A multidimensional perspective on reputation as an intangible asset. In The Oxford Handbook of Corporate Reputation. Barnett ML, Pollock TG (eds.), Oxford University Press.

Rindova VP, Williamson IO, Petkova AP, Sever JM. 2005. Being good or being known: An empirical examination of the dimensions, antecedents, and consequences of organizational reputation. Academy of Management Journal 48(6): 1033-1049.

Rossman G, Schilke O. 2014. Close, but no cigar: The bimodal rewards to prize-seeking. American Sociological Review 79(1): 86-108.

Sadowski M. 2010. Rate the raters phase one: Look back and current state, SustainAbility.

Sadowski M, Whitaker K, Buckingham F. 2010. Rate the raters phase two: Taking inventory of the ratings universe, SustainAbility.

Shocker AD, Ben-Akiva M, Boccara B, Nedungadi P. 1991. Consideration set influences on consumer decision-making and choice: Issues, models, and suggestions. Marketing Letters 2(3): 181-197.

Srinivasan R, Lilien GL, Sridhar S. 2011. Should firms spend more on research and development and advertising during recessions? Journal of Marketing 75(3): 49-65.

Tian Y, Smith EB, King B. 2019. Effect of organizational status on employment-related corporate social responsibility, Northwestern University.

Waddock S, Graves S, Kelly M. 2000. On the trail of the best corporate citizens. Business Ethics 14(2): 17.

Waguespack DM, Sorenson O. 2011. The ratings game: Asymmetry in classification. Organization Science 22(3): 541-553.

Wright P, Ferris SP, Hiller JS, Kroll M. 1995. Competitiveness through management of diversity: Effects on stock price valuation. Academy of Management Journal 38(1): 272287. 


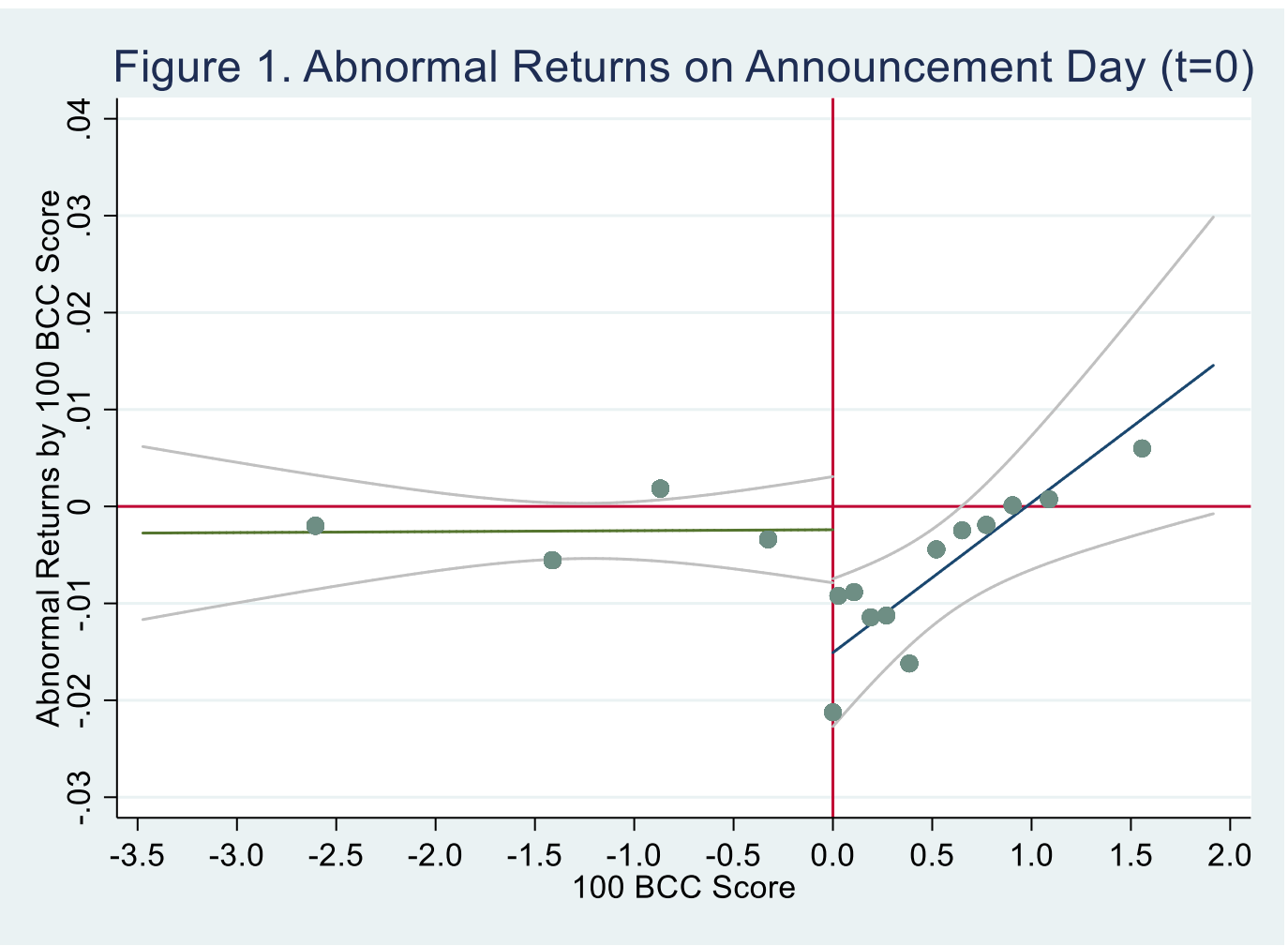

Notes: The vertical axis indicates the abnormal returns on the day of the announcement. Abnormal returns are computed using the market model. The horizontal axis indicates the 100 BCC Score with 0 indicating the inclusion threshold. Firms with positive ranks were included on the list while with negative ranks were excluded. Each dot in the figure represents the average abnormal return within an optimized bin-width (IMSE) calculated for each side of the threshold using the STATA command, rdplot with quantile spacing (Calonico et al., 2017; Calonico, Cattaneo, and Titiunik, 2015). The solid line plots predicted values of abnormal returns form first-order polynomials in 100 BCC score estimated separately to the left and right of the inclusion threshold. The light gray lines represented $95 \%$ confidence intervals. 
Table 1. Summary Statistics

\begin{tabular}{lrrrrrr}
\hline Variable & $\mathrm{N}$ & Mean & Median & SD & 10th \%tile & 90th \%tile \\
\hline Abnormal return on announcement day & 513 & -0.003 & -0.005 & 0.029 & -0.034 & 0.026 \\
KLD index & 513 & 0.893 & 1 & 2.616 & -2 & 4 \\
Total assets (\$ million) & 513 & 18,698 & 5,008 & 50,044 & 590 & 37,156 \\
Market value (\$ million) & 513 & 17,471 & 4,689 & 43,588 & 507 & 39,024 \\
ROA & 513 & 0.059 & 0.050 & 0.049 & 0.006 & 0.131 \\
Cash & 513 & 0.072 & 0.033 & 0.087 & 0.006 & 0.209 \\
Leverage & 513 & 0.264 & 0.274 & 0.145 & 0.044 & 0.462 \\
Institutional ownership & 513 & 0.609 & 0.629 & 0.141 & 0.405 & 0.784 \\
Analyst coverage & 513 & 20.856 & 20 & 12.169 & 6 & 36 \\
DS 400 & 513 & 0.626 & 1 & 0.484 & 0 & 1 \\
DJSI & 513 & 0.072 & 0 & 0.259 & 0 & 0 \\
B2B industry & 513 & 0.708 & 1 & 0.455 & 0 & 1 \\
\hline Not: Abn
\end{tabular}

Notes: Abnormal returns on the announcement day are computed using the market model. KLD index is measured in the calendar year prior to the announcement date. All financial variables are obtained from Compustat and computed in the fiscal year that ends prior to the announcement day. Total assets is the book value of total assets (AT). Market value is the number of shares outstanding (CSHO) multiplied by the stock price at end of the fiscal year prior to announcement day (PRCC_F). Return on Assets (ROA) is measured as the ratio of net income (NI) to book value of assets (AT). Cash is the ratio of cash and short-term investments (CHE) to total assets (AT). Leverage is the ratio of debt in current liabilities (DLC) and long-term debt (DLTT) to total assets (AT). Institutional Ownership is the proportion of shares owned by institutional investors from the Thomson Reuters Institutional Managers Holdings database in the prior year. Analyst Coverage is the number of unique analyst estimates in the I/B/E/S database in the prior year. DS 400 and DJSI are indicator variables equal to 1 if the firm was a member of the Domini Social 400 Index or the Dow Jones Sustainability Index respectively, and 0 otherwise. B2B industry is an indicator variable equal to 1 if the company operates in a business-to-business (B2B) industry and 0 otherwise. All ratios are winsorized at the 5 th and 95th percentiles of their empirical distribution. 
Table 2. Preexisting Differences as a Function of the 100 BCC Score

\begin{tabular}{|c|c|c|c|c|}
\hline & \multicolumn{4}{|c|}{ Before Announcement (t-1) } \\
\hline & $\begin{array}{r}\text { Diff-in-means } \\
\text { (Full Sample) }\end{array}$ & $\begin{array}{r}\text { Diff-in-means } \\
{[-30,+30]}\end{array}$ & $\begin{array}{r}\text { Diff-in-means } \\
{[-20,+20]}\end{array}$ & $\begin{array}{r}\text { RDD estimate } \\
\text { (Full Model) }\end{array}$ \\
\hline & (1) & $(2)$ & (3) & (4) \\
\hline \multirow[t]{2}{*}{ Abnormal return } & -0.002 & -0.012 & -0.005 & -0.005 \\
\hline & 0.589 & 0.463 & 0.669 & 0.393 \\
\hline \multirow[t]{2}{*}{ KLD index } & 3.835 & 0.167 & -0.250 & 0.357 \\
\hline & 0.000 & 0.714 & 0.651 & 0.292 \\
\hline \multirow[t]{2}{*}{ Total assets (log) } & 0.478 & -0.128 & 0.485 & -0.048 \\
\hline & 0.013 & 0.771 & 0.354 & 0.905 \\
\hline \multirow[t]{2}{*}{ Market value (log) } & 0.984 & -0.416 & -0.400 & -0.593 \\
\hline & 0.000 & 0.341 & 0.456 & 0.123 \\
\hline \multirow[t]{2}{*}{ ROA } & 0.021 & -0.007 & -0.019 & -0.010 \\
\hline & 0.000 & 0.601 & 0.225 & 0.260 \\
\hline \multirow[t]{2}{*}{ Cash } & 0.027 & 0.019 & 0.027 & -0.005 \\
\hline & 0.012 & 0.442 & 0.403 & 0.757 \\
\hline \multirow[t]{2}{*}{ Leverage } & -0.034 & -0.004 & 0.038 & 0.023 \\
\hline & 0.056 & 0.924 & 0.402 & 0.412 \\
\hline \multirow[t]{2}{*}{ Institutional ownership (\%) } & -0.028 & -0.008 & -0.059 & -0.003 \\
\hline & 0.074 & 0.830 & 0.194 & 0.907 \\
\hline \multirow[t]{2}{*}{ Analyst coverage } & 5.806 & -4.167 & -5.650 & -2.729 \\
\hline & 0.000 & 0.193 & 0.131 & 0.336 \\
\hline \multirow[t]{2}{*}{ DS 400} & 0.316 & 0.200 & 0.100 & 0.130 \\
\hline & 0.000 & 0.069 & 0.442 & 0.179 \\
\hline \multirow[t]{2}{*}{ DJSI } & 0.084 & -0.033 & -0.100 & -0.010 \\
\hline & 0.022 & 0.694 & 0.304 & 0.855 \\
\hline \multirow[t]{2}{*}{ B2B industry } & -0.084 & -0.100 & -0.100 & 0.031 \\
\hline & 0.113 & 0.399 & 0.503 & 0.786 \\
\hline
\end{tabular}

Notes: This table tests whether $100 \mathrm{BCC}$ inclusion is systematically related to firm characteristics prior to the announcement day. All variables are defined in Table 1. Column (1) reports the difference-in-means among all firms in the sample; Column (2) reports the difference-in-means among all firms that lie within 30 ranks of the inclusion threshold; Column (3) reports the difference-in-means among all firms that lie within 20 ranks of the inclusion threshold; Column (4) reports the difference at the inclusion threshold by estimating the global parametric RDD specification including first-order or second-order polynomials on both sides of the threshold. Pvalues are shown below each estimate. 
Table 3. Results

\begin{tabular}{|c|c|c|c|c|c|c|}
\hline \multicolumn{7}{|c|}{ Panel A. Abnormal Returns Around the Inclusion Threshold } \\
\hline & \multicolumn{4}{|c|}{ Non-parametric Estimation } & \multicolumn{2}{|c|}{ Parametric Estimation } \\
\hline & All Firms & Non-marginal & {$[-30,+30]$} & {$[-20,+20]$} & & Full Model \\
\hline & $(1)$ & $(2)$ & (3) & $(4)$ & & $(5)$ \\
\hline \multirow[t]{3}{*}{100 BCC Member } & -0.001 & -0.001 & -0.022 & -0.027 & & -0.013 \\
\hline & (0.001) & (0.004) & (0.008) & $(0.010)$ & & $(0.005)$ \\
\hline & 0.169 & 0.742 & 0.007 & 0.007 & & 0.005 \\
\hline R-Squared & 0.003 & 0.000 & 0.028 & 0.139 & & 0.016 \\
\hline Observations & 513 & 453 & 60 & 40 & & 513 \\
\hline \multicolumn{7}{|c|}{ Panel B. Moderating Effects of the Specificity, Consistency, and Materiality of CSR Investments } \\
\hline & \multicolumn{2}{|c|}{ Specificity of CSR } & \multicolumn{2}{|c|}{ Consistency of CSR } & \multicolumn{2}{|c|}{ Relevancy of CSR } \\
\hline & No & Yes & No & Yes & No & Yes \\
\hline & $(1)$ & $(2)$ & $(3)$ & $(4)$ & $(5)$ & $(6)$ \\
\hline \multirow[t]{3}{*}{100 BCC Member } & -0.017 & -0.007 & -0.019 & -0.006 & -0.017 & -0.002 \\
\hline & $(0.005)$ & $(0.007)$ & $(0.007)$ & $(0.007)$ & $(0.006)$ & $(0.008)$ \\
\hline & 0.002 & 0.340 & 0.005 & 0.363 & 0.003 & 0.831 \\
\hline \multirow[t]{2}{*}{ F-Tests: Differences between columns } & & 4.180 & & 4.580 & & 5.060 \\
\hline & & 0.041 & & 0.033 & & 0.025 \\
\hline R-squared & 0.038 & 0.004 & 0.032 & 0.005 & 0.021 & 0.034 \\
\hline Observations & 265 & 248 & 219 & 294 & 363 & 150 \\
\hline
\end{tabular}

Notes. In all regressions, we report coefficients followed by the standard error and respective $p$-values. Panel A presents regressions of the abnormal returns on the day of the announcement of the $100 \mathrm{BCC}$ list on the $100 \mathrm{BCC}$ inclusion dummy, i.e. a dummy variable that equals 1 if the firm is recognized as a member of the list and 0 otherwise. In Panel B, we explore moderating effects of a prior reputation by splitting the full sample into various subsamples. We test for significant differences between subsamples using an F-Test in a fully interacted model (i.e. the moderating variable interacted with each covariate from the baseline parametric model) as shown in the Appendix, Tables A7-A9.. 


\section{ONLINE APPENDIX:}

\section{Nonparametric and parametric estimation in a regression discontinuity design (RDD)}

Conceptually, the treatment effect of $B C C_{i}$ can be estimated by finding the difference in the average $y_{i}$ for firms just above or below the inclusion threshold. This simplified comparison of means is known as nonparametic or local estimation (Angrist \& Pischke, 2009, 2015). While this computation does provide an unbiased estimate of $100 \mathrm{BCC}$ inclusion on shareholder value (Flammer, 2015a), it nevertheless discards firms with scores that are farther away from the threshold which may limit statistical power (Jacob, Zhu, Somers, \& Bloom, 2012). Fortunately, a more precise estimate can be calculated by evaluating all ranked firms and approximating the continuous relationship between $y_{i}$ and $S_{i}$, allowing for a discontinuity at the inclusion threshold $S^{*}$. This approach is known as parametric or global estimation. While this method of estimation is likely to be more precise (i.e. produce smaller standard errors), it can also produce biased estimates if the functional form between the outcome variable $\left(y_{i}\right)$ and ranking variable $\left(S_{i}\right)$ is misspecified. Both methods, nonparametic and parametric estimation, thus represent a tradeoff between bias and precision. To address these concerns, RD scholars have suggested that researchers use and compare both estimation methods as a way to evaluate the robustness of their results (Jacob et al., 2012; Lee \& Lemieux, 2010). We follow these recommendations closely.

\section{Graphical analysis of covariates}

We also plot each covariate against the overall BCC score and find no indication of significant discontinuities at threshold as shown in Figure A3, panels (A) - (L) of the Appendix. We specifically use the STATA command cmogram to plot each covariate against the overall BCC score. The dashed vertical line centered at 0 represents the inclusion threshold. Each dot represents the mean of the focal variable for firms within 50 equally spaced bins. The solid green lines plot predicted values of each 
variable using first- or second-order polynomial functions. The optimal function was determined using the AIC statistics (Lee \& Lemieux, 2010). The light gray lines bounding the predicted values represent $95 \%$ confidence intervals.

\section{Robustness tests}

In Table A4, we conduct a number of robustness checks to ensure confidence in our baseline estimate of $-1.3 \%$.

Baseline Model. The baseline model, also shown in column (5) of Table 3, includes first-order polynomials in the $100 \mathrm{BCC}$ score on each side of the threshold using the market model to compute abnormal returns. Subsequent specifications will vary the details of this baseline specification to evaluate the robustness of this estimate.

Control Variables. This specification adds all control covariates as shown in Table 2 for year t- 1 , with the exception of the Abnormal return variable. If the RD design is valid, we should see no substantive changes in the coefficient with the inclusion of control variables (Lee \& Lemieux, 2010), signifying that all predetermined covariates are orthogonal to the assignment of "inclusion" or "exclusion" near the threshold. As shown in column (2), the coefficient is indeed the same when including all control variables providing support for the validity of our RD design.

Market-Adjusted. We evaluate whether our findings are robust to alternative models for computing abnormal returns. In column (3), we display the estimated abnormal return using the market adjusted model (Madsen \& Rodgers, 2015). Consistent with the market model, we find a significant $-1.3 \%$ decline in firm value on the announcement day. Compared with our baseline estimate in column (1), this result suggests that our main effect, a decrease in firm value for marginal firms, is not sensitive to an alternative method of computing abnormal returns. 
Confound Events. We also consider whether our results can be explained by confounding events (McWilliams \& Siegel, 1997). To address this concern, we exclude from our sample all firms $(\mathrm{n}=11)$ that announced a dividend, earnings, or a merger or acquisition on the day that the $100 \mathrm{BCC}$ list was announced. As displayed in column (4), we find nearly identical results when we exclude these 11 firms. This finding suggests that confounding events do not seem to be driving our primary result.

Influence of Outliers. We evaluate whether our main finding is driven by a few large abnormal returns near the inclusion threshold. To thus address the influence of potential outliers, we first reestimate the model in column (1) after replacing the dependent variable equal to 1 if the abnormal return is positive and 0 otherwise. This specification is unlikely to be influenced by outliers given that the dummy variable ignores the magnitude of the coefficient. As shown in column (5), firms that barely make the list are $18.2 \%$ less likely to experience a positive return on the day of announcement compared to firms that barely miss the list.

We also test for the influence of outliers by trimming the most extreme observations in the distribution of abnormal returns (Jacob et al., 2012). Specifically, as shown in columns (6) - (8), we remove the outermost $1 \%, 5 \%$, and $10 \%$ of the data. This exercise yields a statistically significant estimate for the effect of marginal inclusion that ranges between $1.0 \%$ and $1.3 \%$. This result gives us confidence that our primary estimate is not being driven by the influence of outliers.

Placebo Cutoffs. As the name of the list describes, the cutoff for inclusion on the $100 \mathrm{BCC}$ list lies at the $100^{\text {th }}$ ranked firm. To ensure that the discontinuity that we observe is not one that would be expected by chance alone, we examine alternative placebo cutoffs at the $200^{\text {th }}, 300^{\text {th }}, 400^{\text {th }}$, and $500^{\text {th }}$ ranked firm. Evidence of a significant discontinuity at any of these thresholds would cast doubt that that observed discontinuity at the $100^{\text {th }}$ firm was not produced by random error. As shown in columns 
(9) - (12), we find no significant discontinuity at any of the placebo cutoffs, which lends strong support to the validity of our RD specification.

Dynamic RDD. In column (13), we use a dynamic RDD specification to examine whether marginal inclusion on the $100 \mathrm{BCC}$ has an effect on firm value beyond the announcement day. Following prior research (Cuñat, Gine, \& Guadalupe, 2012; Flammer, 2015a; Flammer \& Bansal, 2017), we account for multiple days by creating a panel data set in which, for each firm $i$ on announcement day $t$, observations at time $t+\tau$ are pooled for multiple $\tau$ ranging from $t-2$ to $t+7$. Because observations before and after the announcement are pooled together, we can include a firm fixed effect $\alpha_{i}$ to control for unobservable firm characteristics that are constant during the analysis window. Similar with our baseline result, we find a $1.4 \%$ decrease in firm value for marginal firms that are included on the list relative to marginal firms that are excluded. Following the announcement day, however, we find positive, but small and insignificant abnormal returns. Together these results suggest that investors react to the information contained in the rankings on the announcement day, when the "new" information is likely to be most salient.

\section{Moderating effects: Specificity, consistency, and relevancy of CSR investments}

Specificity of CSR. We evaluate the specificity of CSR by computing the standard deviation of ratings amongst the four stakeholder groups evaluated by the BCC list: community, employees, customers, and shareholders. Firms that have concentrated their investments in one particular domain are likely to have a higher standard deviation than firms whose investments were spread more equally. For example, Figure A4 displays the Community Relations, Employee Relations, and Customer Relations sub-ratings for Timberland Co. (ranked 92nd) and PNC Financial Services Group (ranked 94th). Although both companies had similar BCC scores (hence the similar ranks), it is clear that 
Timberland's investments in corporate citizenship were more focused on the community whereas PNC's investments were spread more evenly across domains.

Consistency of CSR. To evaluate the consistency of CSR, we compute the change in the KLD index between 1999 (t-1) and 1996 (t-4). We then classify firms into two groups: (1) those whose change in the KLD index was greater than 0 (No History of CSR) and (2) those whose change in the KLD index was less than or equal to 0 (History of CSR). Firms with significantly positive differences are not likely to have a well-established history of CSR investments (see the For example, Lucent Technologies (ranked 68th) increased its KLD index score (from 1 to 9) from 1996-1999 more than any firm in our sample. While such a sharp increase was enough to catapult Lucent onto the list, it is unlikely that investors perceived Lucent as having a strong history of making CSR investments.

Relevancy of CSR. To evaluate the relevancy of CSR, we compute the ratio of a firm's KLD strengths that are likely to be considered to be material by the Sustainability Accounting Standards Board (SASB) to the overall material KLD strengths within an industry. We focus on the KLD strengths rather than concerns because (1) recent work suggests that KLD's strengths and concerns lack convergent validity (Flammer, 2015b, 2018; Flammer \& Bansal, 2017; Flammer \& Luo, 2017) and (2) the strengths evaluate proactive activities and initiatives that are largely under the control and discretion of the firm (Walls, Berrone, \& Phan, 2012) and thus more easy for firm to manipulate in order for them to manage their socially responsible reputation.

To classify each KLD strength as material or immaterial we follow guidance from the SASB Materiality Map for each firm in our sample. Firms are allocated to one of 11 sectors and 77 industries according to the Sustainability Industrial Classification System (SICS). ${ }^{1}$ For each industry, the SASB

\footnotetext{
${ }^{1}$ We found each firm's SICS classification using the following URL: https://www.sasb.org/find-your-industry/
} 
map identifies 26 sustainability-related issues and indicates whether the issue is likely to be material for companies within that particular industry. We display the materiality map at the sector level in Table A5. Following guidance from recent research (Khan, Serafeim, \& Yoon, 2016), we assign KLD strength items to a one or more of the 26 identified by the SASB using a mapping provided in Table A6.

Interaction Effects. We also seek to provide additional transparency by demonstrating that the split sample analysis used to test the moderating effects of specificity, consistency, and relevance is in fact equivalent to interacting each variable in the initial parametric model by the moderating variables (see also Chatterji and Toffel, 2010).

We begin by displaying the subsample results found in Table 3 with the controls for the distance from the inclusion threshold in as shown in Panel A, Table A7-A9. We then display the full interaction model in Panel B (the original covariates from the baseline model interacted with the moderating effect indicator) in order to (1) evaluate the difference between the coefficients in each subsample using an Ftest, and (2) to demonstrate that the interaction analysis leads to the same results as the subsample analysis. 


\section{Figure A1. Distribution of BCC Scores}

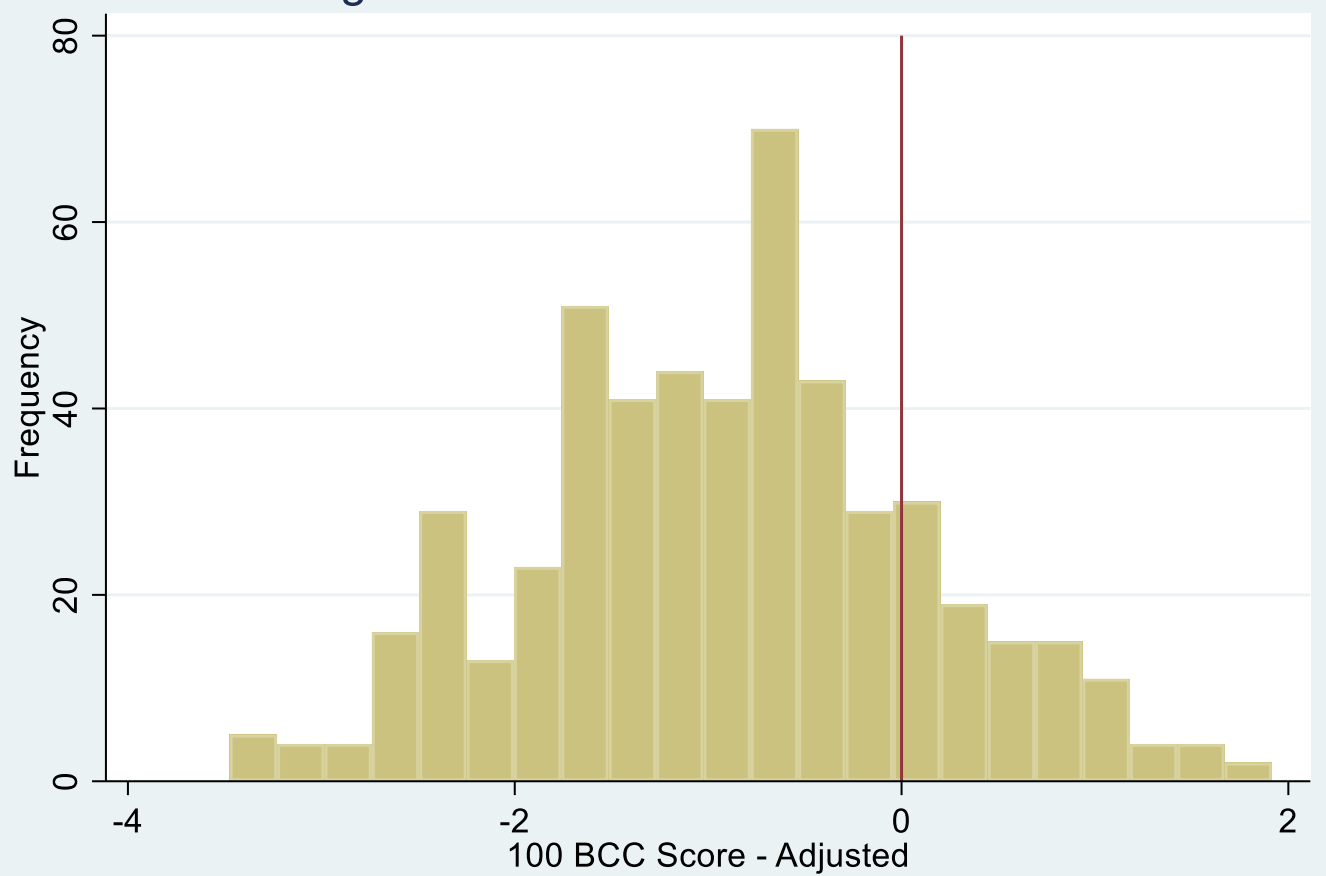

Notes. This figure presents the distribution of 100 BCC scores in the year 2000. The horizontal axis indicates the standardized $100 \mathrm{BCC}$ score with scores greater than or equal to zero indicating inclusion on the $100 \mathrm{BCC}$ list. The vertical axis indicates the frequency of $100 \mathrm{BCC}$ scores. 


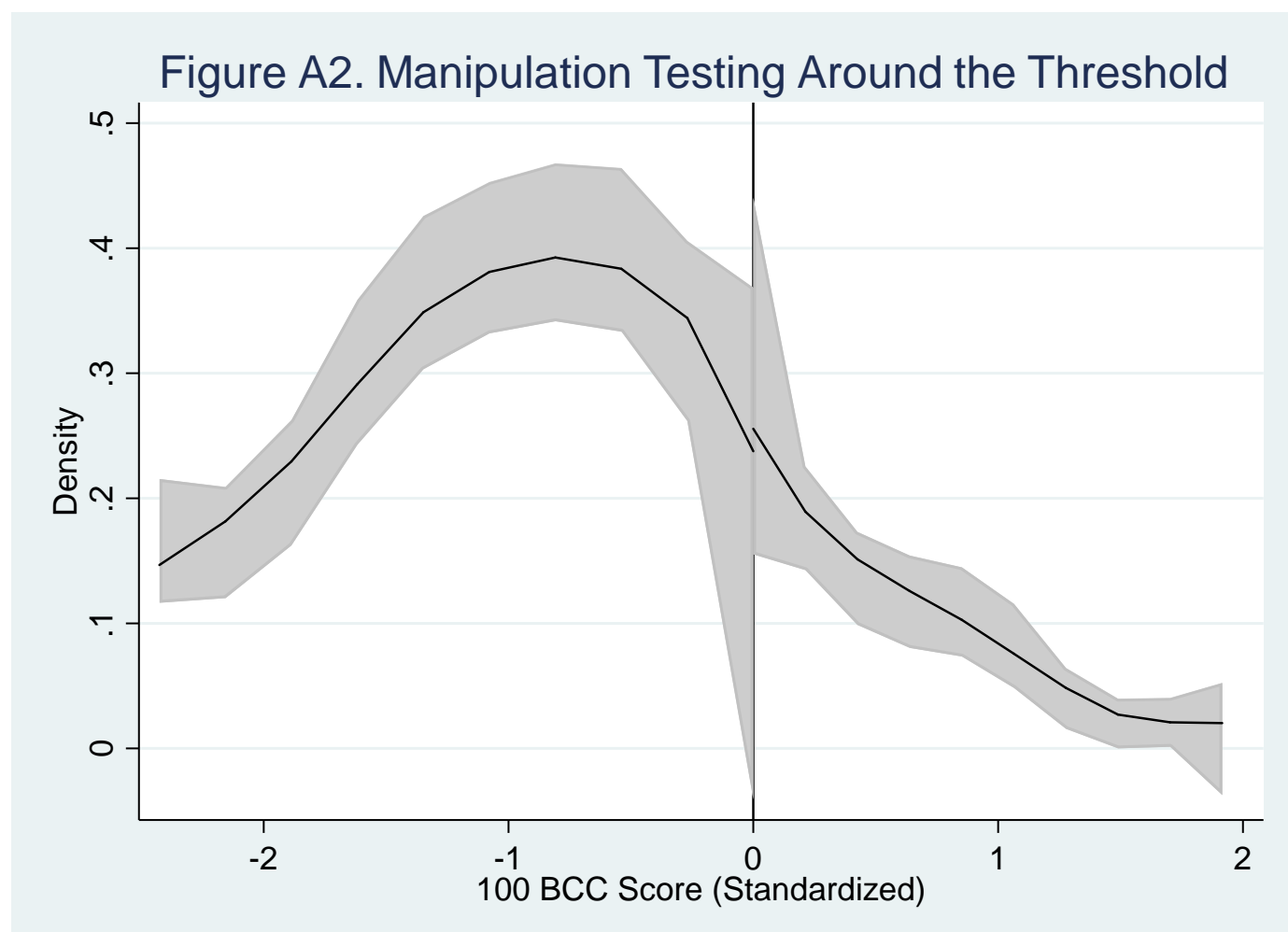

Notes. This figure presents a visualization of the rddensity command in STATA developed by Cattaneo et al. (2017). The horizontal axis indicates the $100 \mathrm{BCC}$ score (standardized). The vertical axis indicates the logarithm of the estimated density. 
Figure A3. Graphical analysis of covariates
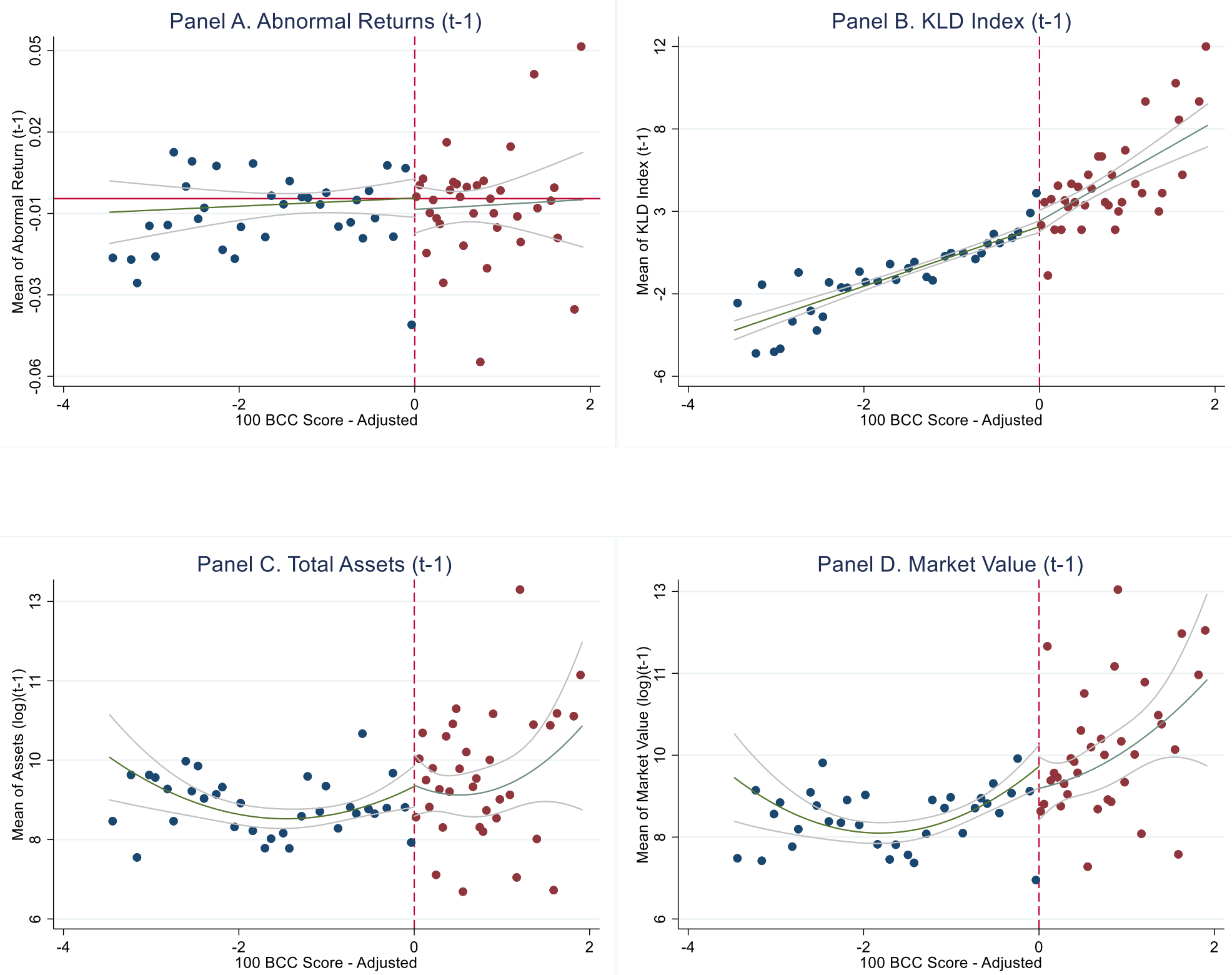

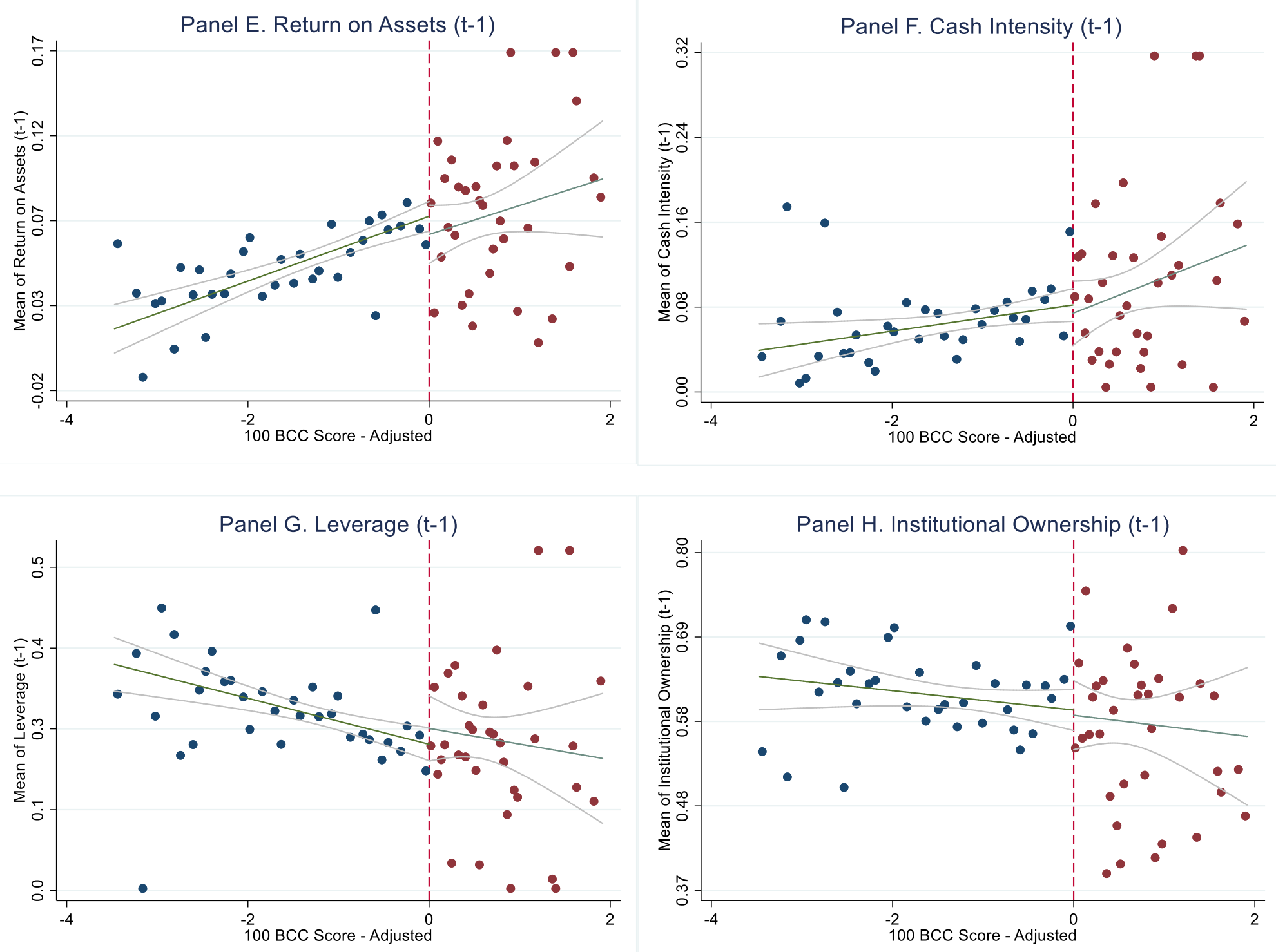

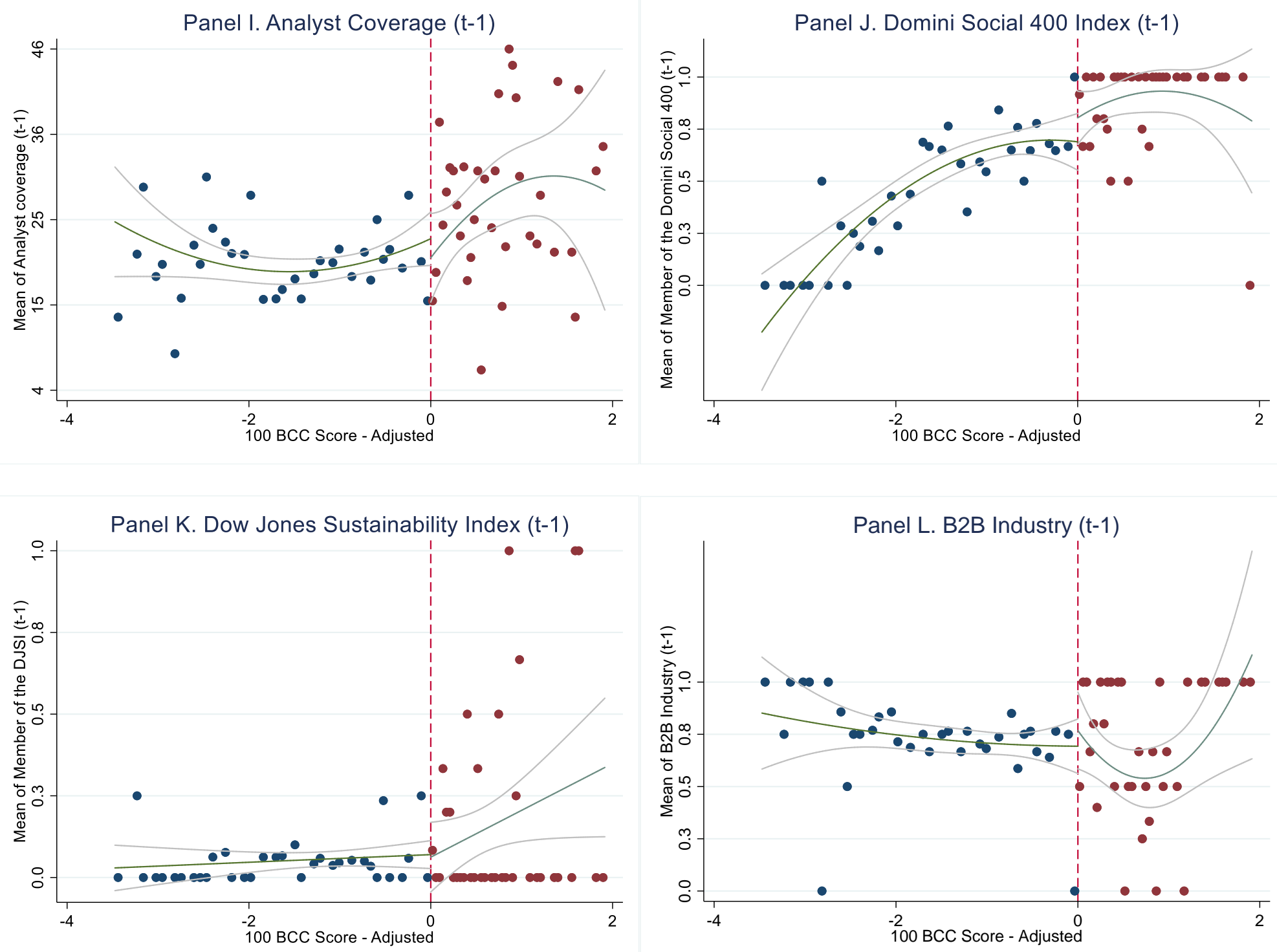


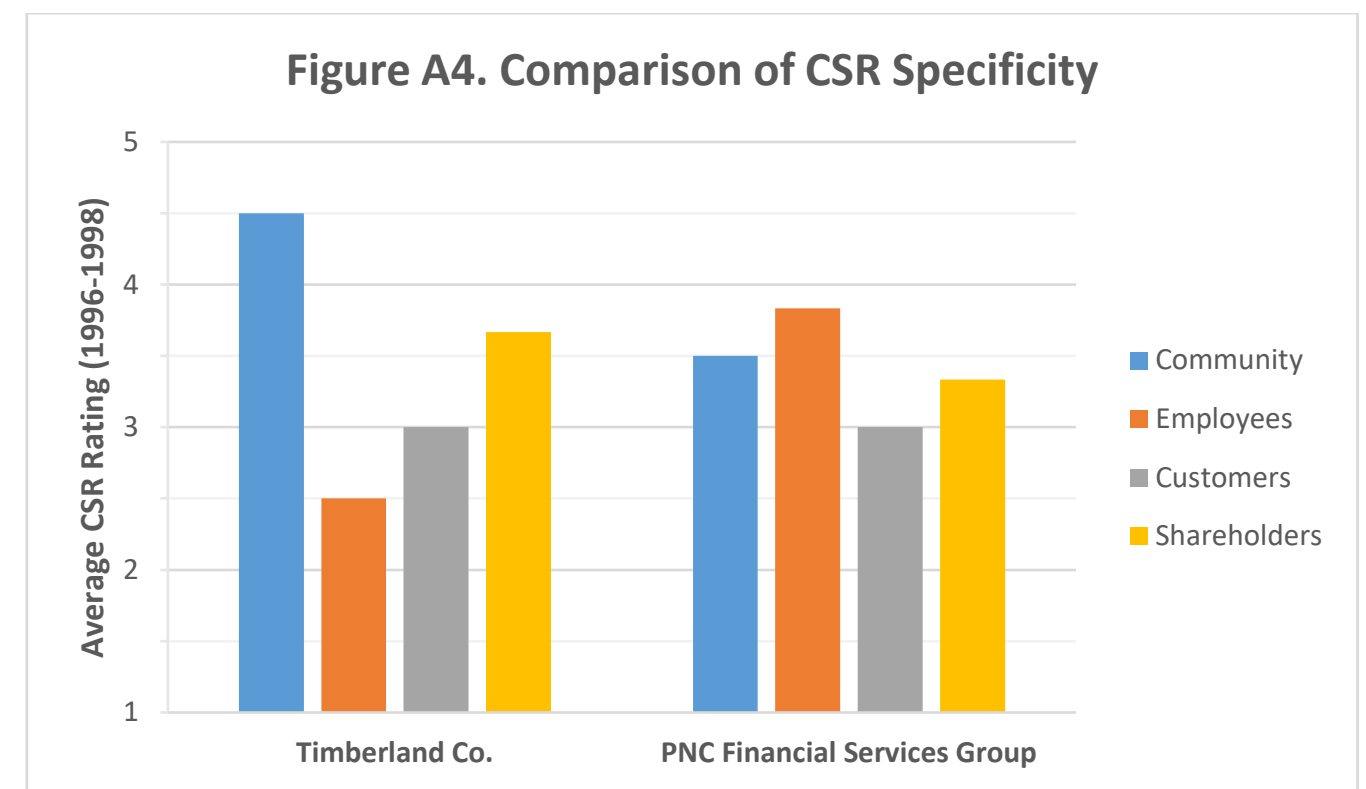

Notes. Sub-ratings range from a minimum value of 1 to maximum of 5. See the Notes in Table 2 for more information about how the sub-ratings were calculated. 
Table A1. Snapshot of the 100 Best Corporate Citizen's List for the Year 2000

\begin{tabular}{|c|c|c|c|c|c|c|c|c|c|c|}
\hline Rank & $\begin{array}{r}\text { Overall } \\
\text { rating }\end{array}$ & Company name & & $\begin{array}{l}\text { Revenues } \\
\text { (millions) }\end{array}$ & & $\begin{array}{r}\text { Vet income } \\
\text { (millions) }\end{array}$ & $\begin{array}{r}\begin{array}{r}\text { Total return } \\
\text { to } \\
\text { shareholders }\end{array}\end{array}$ & $\begin{array}{r}\text { Community } \\
\text { relations }\end{array}$ & $\begin{array}{r}\text { Employee } \\
\text { relations }\end{array}$ & $\begin{array}{l}\text { Customer } \\
\text { relations }\end{array}$ \\
\hline 1 & 4.15167 & IBM & $\$$ & $87,548.0$ & $\$$ & $7,712.0$ & $61.39 \%$ & 4.50 & 4.33 & 3.33 \\
\hline 2 & 4.11000 & Hewlett Packard & $\$$ & $42,370.0$ & $\$$ & $3,491.0$ & $19.01 \%$ & 4.33 & 5.00 & 4.00 \\
\hline 3 & 4.04500 & Intel & $\$$ & $29,389.0$ & $\$$ & $7,314.0$ & $69.26 \%$ & 3.67 & 4.50 & 4.00 \\
\hline 4 & 4.04167 & Procter \& Gamble & $\$$ & $38,125.0$ & $\$$ & $3,763.0$ & $32.69 \%$ & 3.83 & 4.67 & 4.00 \\
\hline 5 & 4.02167 & Herman Miller & $\$$ & $1,766.2$ & $\$$ & 141.8 & $61.55 \%$ & 4.00 & 4.83 & 3.33 \\
\hline 6 & 4.01833 & Xerox & $\$$ & $19,228.0$ & $\$$ & $1,424.0$ & $40.94 \%$ & 4.17 & 5.00 & 3.00 \\
\hline 7 & 3.96000 & Tellabs & $\$$ & 2,319.5 & $\$$ & 559.1 & $57.86 \%$ & 3.00 & 3.67 & 5.00 \\
\hline 8 & 3.93667 & Charles Schwab & $\$$ & $4,713.2$ & $\$$ & 588.9 & $86.51 \%$ & 3.00 & 4.33 & 3.67 \\
\hline 9 & 3.87667 & Fannie Mae & $\$$ & $36,968.0$ & $\$$ & $3,912.0$ & $36.84 \%$ & 4.00 & 3.67 & 4.00 \\
\hline 10 & 3.87000 & Times Mirror Company & $\$$ & $3,029.2$ & $\$$ & 259.1 & $21.70 \%$ & 4.33 & 4.00 & 4.00 \\
\hline 11 & 3.86333 & DeVry Incorporated & $\$$ & 419.4 & $\$$ & 38.8 & $67.29 \%$ & 3.00 & 4.00 & 4.00 \\
\hline 12 & 3.84000 & Pitney Bowes & $\$$ & $4,432.6$ & $\$$ & 636.2 & $45.73 \%$ & 4.33 & 4.00 & 3.00 \\
\hline 13 & 3.83833 & Solectron & $\$$ & $8,391.4$ & $\$$ & 293.9 & $66.77 \%$ & 3.00 & 4.17 & 4.00 \\
\hline 14 & 3.83500 & Southwest Airlines & $\$$ & $4,735.6$ & $\$$ & 474.4 & $34.14 \%$ & 3.33 & 4.50 & 4.00 \\
\hline 15 & 3.83167 & Kroger Company & $\$$ & $45,352.0$ & $\$$ & 628.0 & $49.04 \%$ & 3.83 & 4.33 & 3.00 \\
\hline 16 & 3.79333 & Compaq Computer & $\$$ & $38,525.0$ & $\$$ & 569.0 & $64.65 \%$ & 3.17 & 3.50 & 4.00 \\
\hline 17 & 3.79167 & Walt Disney Company & $\$$ & $23,402.0$ & $\$$ & $1,300.0$ & $17.80 \%$ & 4.00 & 3.83 & 4.33 \\
\hline 18 & 3.79000 & Ben \& Jerry's Homemade & $\$$ & 237.0 & $\$$ & 3.4 & $20.20 \%$ & 4.50 & 4.50 & 3.00 \\
\hline 19 & 3.78000 & Whole Foods Market & $\$$ & $1,567.9$ & $\$$ & 42.2 & $61.34 \%$ & 4.17 & 4.17 & 3.00 \\
\hline 20 & 3.77833 & The Gap & $\$$ & $11,635.4$ & $\$$ & $1,127.1$ & $87.00 \%$ & 3.50 & 4.00 & 3.00 \\
\hline
\end{tabular}

Notes. This table lists the top 20 companies on the 100 BCC ranking in the year 2000. The community relations measure is a three-year average (1996-1998) of the KLD community and environmental dimensions. The employee relations measure is a three-year average (1996-1998) of the KLD employee and diversity dimensions. The consumer relations measure is a three-average (1996-1998) of the KLD product dimension. The total return to shareholders (1996-1998) is computed using data from Compustat and CRSP. To be consistent with KLD measures, this raw number is converted into quintiles (top 20 percent, next 20 percent, etc.). These four groups are then averaged to compute the overall rating. Financial data (revenues and net income) are obtained from the latest annual reports that precede the announcement date. For more details see Waddock et al. (2000). 


\begin{tabular}{|c|c|c|c|c|c|c|}
\hline \multirow[b]{2}{*}{$\begin{array}{l}\text { SIC } \\
\text { codes }\end{array}$} & \multirow[b]{2}{*}{ Division description } & \multirow[b]{2}{*}{$\begin{array}{l}\text { Number } \\
\text { of firms }\end{array}$} & \multicolumn{2}{|c|}{$\begin{array}{c}\text { Included in the } \\
100 \mathrm{BCC}\end{array}$} & \multicolumn{2}{|c|}{$\begin{array}{l}\text { Excluded from the } \\
100 \mathrm{BCC}\end{array}$} \\
\hline & & & Count & $\%$ & Count & $\%$ \\
\hline 01-09 & Agriculture, Forestry, And Fishing & 0 & 0 & 0 & 0 & 0 \\
\hline $10-14$ & Mining & 19 & 0 & 0 & 19 & 100 \\
\hline $15-17$ & Construction & 6 & 1 & 17 & 5 & 83 \\
\hline 20-39 & Manufacturing & 279 & 54 & 19 & 225 & 81 \\
\hline $40-49$ & Transportation, Communications, Electric, Gas, And Sanitary Services & 64 & 10 & 16 & 54 & 84 \\
\hline $50-51$ & Wholesale Trade & 14 & 0 & 0 & 14 & 100 \\
\hline $52-59$ & Retail Trade & 41 & 10 & 24 & 31 & 76 \\
\hline $60-67$ & Finance, Insurance, And Real Estate & 57 & 20 & 35 & 37 & 65 \\
\hline $70-89$ & Services & 33 & 5 & 15 & 28 & 85 \\
\hline \multirow[t]{2}{*}{$91-97$} & Public Administration & 0 & 0 & 0 & 0 & 0 \\
\hline & Total & 513 & 100 & 19 & 413 & 81 \\
\hline
\end{tabular}

Notes. This table displays the industry composition by SIC divisions among firms evaluated by Business Ethics magazine in the year 2000. We also display subsamples for firms included and excluded for the 100 BCC list. Of the 513 firms in our sample, nearly 20 percent (100/513) were included on the 100 BCC list. A comparison of included and excluded firms reveals that firms that operate in the Retail Trade (SIC codes 52-59) and Finance, Insurance, and Real Estate (SIC codes 60-67) appear to be overrepresented. This result should not be surprising given the strong incentives that consumer facing firms have to maintain socially responsible reputations (Brammer \& Millington, 2008; Lev, Petrovits, \& Radhakrishnan, 2010; Zhang \& Luo, 2013). Other industries notably excluded from the list include metal mining (SIC Code 10), coal mining (SIC Code 12), and oil and gas extraction (SIC Code 13), likely due to their harmful environmental impacts. 


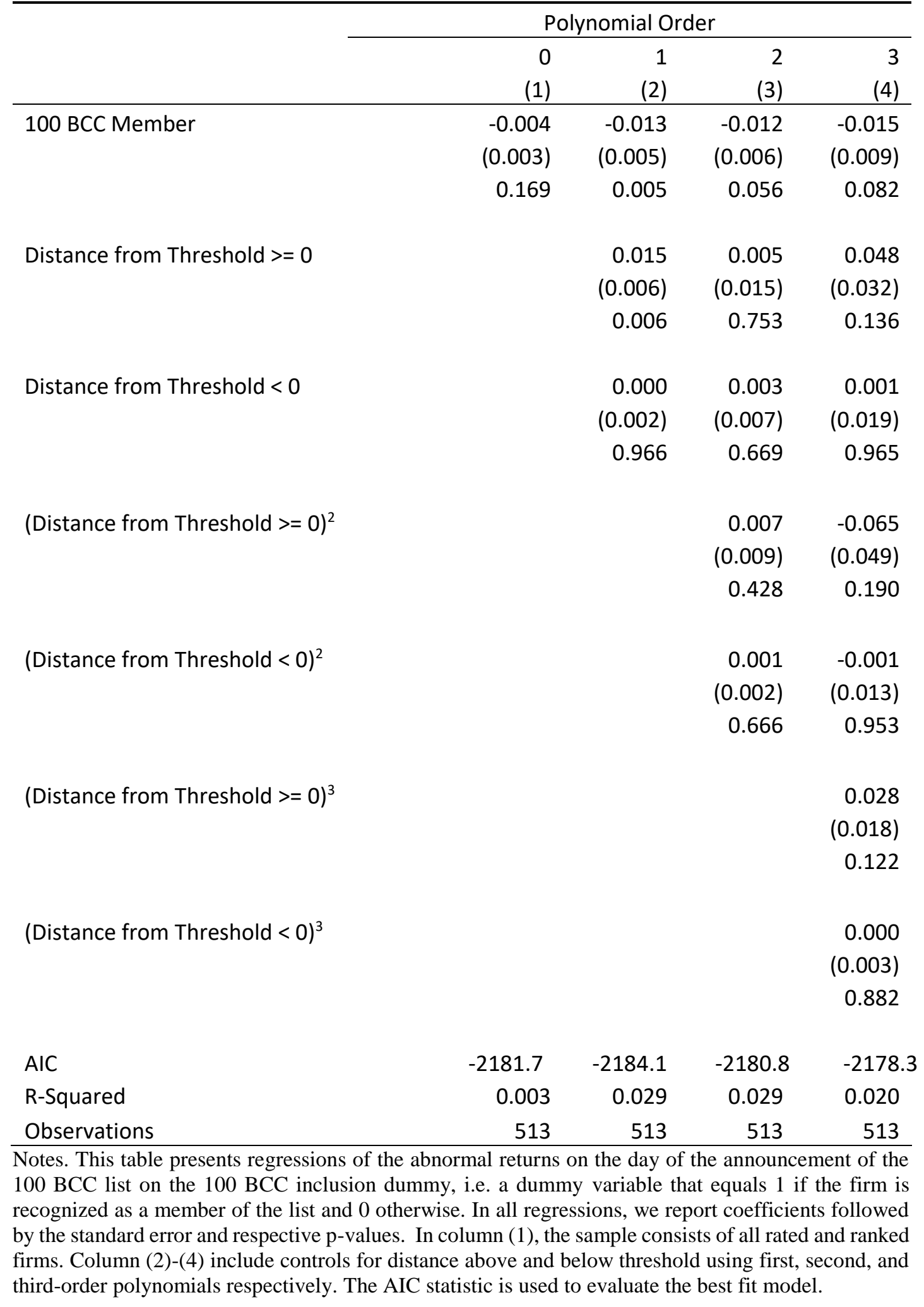


Table A4. Robustness Tests

\begin{tabular}{|c|c|c|c|c|c|c|c|c|c|c|c|c|c|}
\hline & \multirow[b]{2}{*}{$\begin{array}{l}\text { Baseline } \\
\text { Model }\end{array}$} & \multirow[b]{2}{*}{$\begin{array}{r}\text { Control } \\
\text { Variables }\end{array}$} & \multirow[b]{2}{*}{$\begin{array}{l}\text { Market } \\
\text { Adjusted }\end{array}$} & \multirow[b]{2}{*}{$\begin{array}{r}\text { Confound } \\
\text { Events }\end{array}$} & \multicolumn{4}{|c|}{ Influence of Outliers } & \multicolumn{4}{|c|}{ Placebo Cutoffs } & \multirow{3}{*}{$\begin{array}{r}\text { Dynamic } \\
\text { RDD } \\
\text { (13) }\end{array}$} \\
\hline & & & & & $\begin{array}{r}\text { Positive } \\
A R\end{array}$ & $\begin{array}{l}\text { Trim } \\
(1 \%)\end{array}$ & $\begin{array}{l}\text { Trim } \\
(5 \%)\end{array}$ & $\begin{array}{r}\text { Trim } \\
(10 \%)\end{array}$ & $\begin{array}{r}\text { Cut } \\
(200)\end{array}$ & $\begin{array}{r}\text { Cut } \\
(300)\end{array}$ & $\begin{array}{r}\text { Cut } \\
(400)\end{array}$ & $\begin{array}{r}\text { Cut } \\
(500)\end{array}$ & \\
\hline & (1) & $(2)$ & (3) & (4) & (5) & (6) & (7) & (8) & (9) & (10) & (11) & (12) & \\
\hline \multicolumn{14}{|l|}{100 BCC Member } \\
\hline Coefficient & -0.013 & -0.013 & -0.013 & -0.012 & -0.182 & -0.010 & -0.013 & -0.013 & -0.004 & -0.001 & 0.006 & -0.016 & \\
\hline Standard Error & $(0.005)$ & $(0.004)$ & $(0.005)$ & $(0.005)$ & $(0.082)$ & $(0.005)$ & $(0.005)$ & $(0.006)$ & $(0.005)$ & $(0.004)$ & $(0.004)$ & $(0.022)$ & \\
\hline P-value & 0.005 & 0.003 & 0.006 & 0.007 & 0.027 & 0.037 & 0.010 & 0.025 & 0.324 & 0.85 & 0.183 & 0.451 & \\
\hline \multicolumn{14}{|l|}{ Day $(t=0)$} \\
\hline Coefficient & & & & & & & & & & & & & -0.014 \\
\hline Standard Error & & & & & & & & & & & & & $(0.007)$ \\
\hline P-value & & & & & & & & & & & & & 0.040 \\
\hline \multicolumn{14}{|l|}{ One day later $(t+1)$} \\
\hline Coefficient & & & & & & & & & & & & & 0.000 \\
\hline Standard Error & & & & & & & & & & & & & $(0.006)$ \\
\hline P-value & & & & & & & & & & & & & 0.957 \\
\hline \multicolumn{14}{|l|}{ Days $(t+2)$ to $(t+7)$} \\
\hline Coefficient & & & & & & & & & & & & & 0.005 \\
\hline Standard Error & & & & & & & & & & & & & $(0.017)$ \\
\hline P-value & & & & & & & & & & & & & 0.766 \\
\hline R-squared & 0.016 & 0.087 & 0.016 & 0.014 & 0.018 & 0.010 & 0.012 & 0.014 & 0.000 & 0.003 & 0.003 & 0.002 & 0.183 \\
\hline Observations & 513 & 513 & 513 & 502 & 513 & 502 & 463 & 404 & 513 & 513 & 513 & 513 & 2,565 \\
\hline Firms & 513 & 513 & 513 & 502 & 513 & 502 & 463 & 404 & 513 & 513 & 513 & 513 & 513 \\
\hline
\end{tabular}




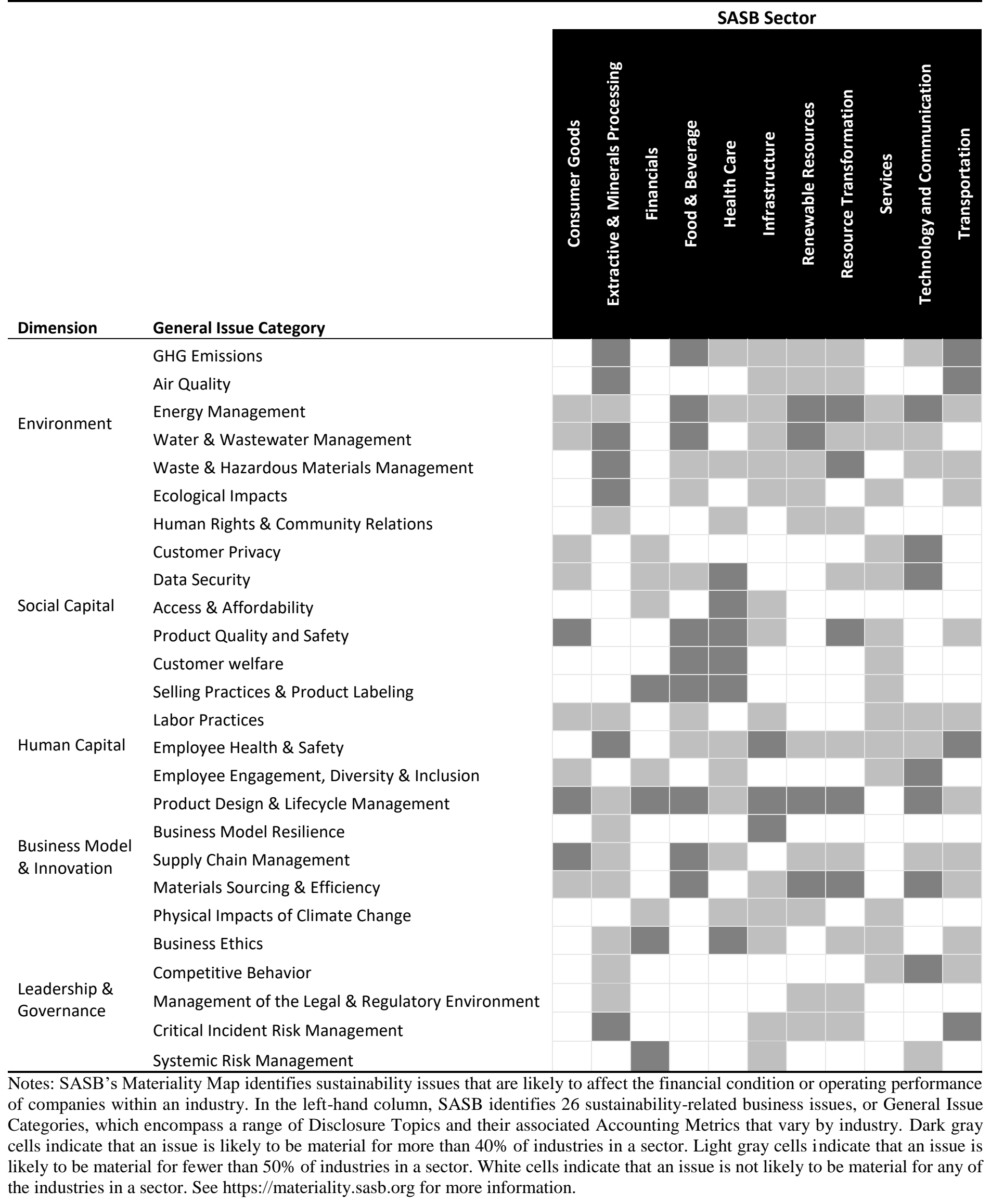


Table A6: Issue Level Designation of KLD Strengths Data

\begin{tabular}{|c|c|c|c|c|}
\hline KLD Category & KLD Rating & KLD Item & SASB Dimension & SASB Issue \\
\hline Community & com_str_a & Charitable Giving & Social Capital & Human Rights \& Community Relations \\
\hline Community & com_str_b & Innovative Giving & Social Capital & Human Rights \& Community Relations \\
\hline Community & com_str_c & Support for Housing & Social Capital & Human Rights \& Community Relations \\
\hline Community & com_str_d & Support for Education & Social Capital & Human Rights \& Community Relations \\
\hline Diversity & div_str_a & CEO & Human Capital & Employee Engagement, Diversity \& Inclusion \\
\hline Diversity & div_str_b & Promotion & Human Capital & Employee Engagement, Diversity \& Inclusion \\
\hline Diversity & div_str_c & Board of Directors & Human Capital & Employee Engagement, Diversity \& Inclusion \\
\hline Diversity & div_str_d & Work/Life Benefits & Human Capital & Labor Practices \\
\hline Diversity & div_str_e & Women \& Minority Contracting & Human Capital & Employee Engagement, Diversity \& Inclusion \\
\hline Diversity & div_str_f & Employment of the Disabled & Human Capital & Employee Engagement, Diversity \& Inclusion \\
\hline Diversity & div_str_g & Gay \& Lesbian Policies & Human Capital & Employee Engagement, Diversity \& Inclusion \\
\hline Employee & emp_str_a & Union Relations & Human Capital & Labor Practices \\
\hline Employee & emp_str_c & Cash Profit Sharing & Human Capital & Labor Practices \\
\hline Employee & emp_str_d & Employee Involvement & Human Capital & Labor Practices \\
\hline Employee & emp_str_f & Retirement Benefits Strength & Human Capital & Labor Practices \\
\hline Employee & emp_str_g & Health and Safety Strength & Human Capital & Employee Health \& Safety \\
\hline Environment & env_str_a & Beneficial Products and Services & Business Model \& Innovation & Product Design \& Lifecycle Management \\
\hline Environment & env_str_b & Pollution Prevention & Environment & Energy Management \\
\hline Environment & env_str_b & Pollution Prevention & Environment & Waste \& Hazardous Materials Management \\
\hline Environment & env_str_c & Recycling & Business Model \& Innovation & Materials Sourcing \& Efficiency \\
\hline Environment & env_str_d & Clean Energy & Environment & Energy Management \\
\hline Environment & env_str_e & Communications & ------ & ------ \\
\hline Product & pro_str_a & Quality & Social Capital & Product Quality \& Safety \\
\hline Product & pro_str_b & R\&D/Innovation & ------- & ------- \\
\hline Product & pro_str_c & Benefits to Economically Disadvantaged & Social Capital & Access \& Affordability \\
\hline
\end{tabular}


Table A7. Moderating Effects of Specific CSR Investments

\begin{tabular}{|c|c|c|c|}
\hline & & \multicolumn{2}{|c|}{ Specificity of CSR } \\
\hline & & No & Yes \\
\hline & & $(1)$ & $(2)$ \\
\hline \multirow{3}{*}{\multicolumn{2}{|c|}{100 BCC Member }} & -0.017 & -0.007 \\
\hline & & $(0.005)$ & $(0.007)$ \\
\hline & & 0.002 & 0.340 \\
\hline \multirow{3}{*}{\multicolumn{2}{|c|}{ BCC Score $<0$}} & 0.000 & 0.000 \\
\hline & & $(0.002)$ & $(0.003)$ \\
\hline & & 0.930 & 0.983 \\
\hline \multirow{3}{*}{\multicolumn{2}{|c|}{ BCC Score $\geq 0$}} & 0.023 & 0.008 \\
\hline & & $(0.007)$ & (0.009) \\
\hline & & 0.002 & 0.369 \\
\hline $\mathrm{R}-\mathrm{sc}$ & uared & 0.038 & 0.004 \\
\hline Obs & rvations & 265 & 248 \\
\hline \multicolumn{4}{|c|}{ Panel B. Interaction Analysis } \\
\hline & 100 BCC Member & & -0.017 \\
\hline & & & $(0.005)$ \\
\hline & & & 0.002 \\
\hline & BCC Score $<0$ & & 0.000 \\
\hline & & & $(0.002)$ \\
\hline & & & 0.930 \\
\hline & BCC Score $\geq 0$ & & 0.023 \\
\hline & & & $(0.007)$ \\
\hline & & & 0.002 \\
\hline & Specificity of CSR & & -0.001 \\
\hline & & & $(0.006)$ \\
\hline & & & 0.871 \\
\hline \multirow{3}{*}{\multicolumn{2}{|c|}{100 BCC Member $\times$ Specificity of CSR }} & & 0.010 \\
\hline & & & $(0.009)$ \\
\hline & & & 0.293 \\
\hline \multirow{3}{*}{\multicolumn{2}{|c|}{ BCC Score $<0 \times$ Specificity of CSR }} & & 0.000 \\
\hline & & & $(0.004)$ \\
\hline & & & 0.950 \\
\hline \multirow{3}{*}{\multicolumn{2}{|c|}{ BCC Score $\geq 0 \times$ Specificity of CSR }} & & -0.015 \\
\hline & & & $(0.011)$ \\
\hline & & & 0.178 \\
\hline \multirow{2}{*}{\multicolumn{2}{|c|}{ F-Test: Coefficient $[\mathrm{A}]=[\mathrm{B}]$}} & & 4.180 \\
\hline & & & 0.041 \\
\hline \multicolumn{2}{|c|}{ R-squared } & & 0.019 \\
\hline \multicolumn{2}{|c|}{ Observations } & & 513 \\
\hline
\end{tabular}


Table A8. Moderating Effects of Consistent CSR Investments

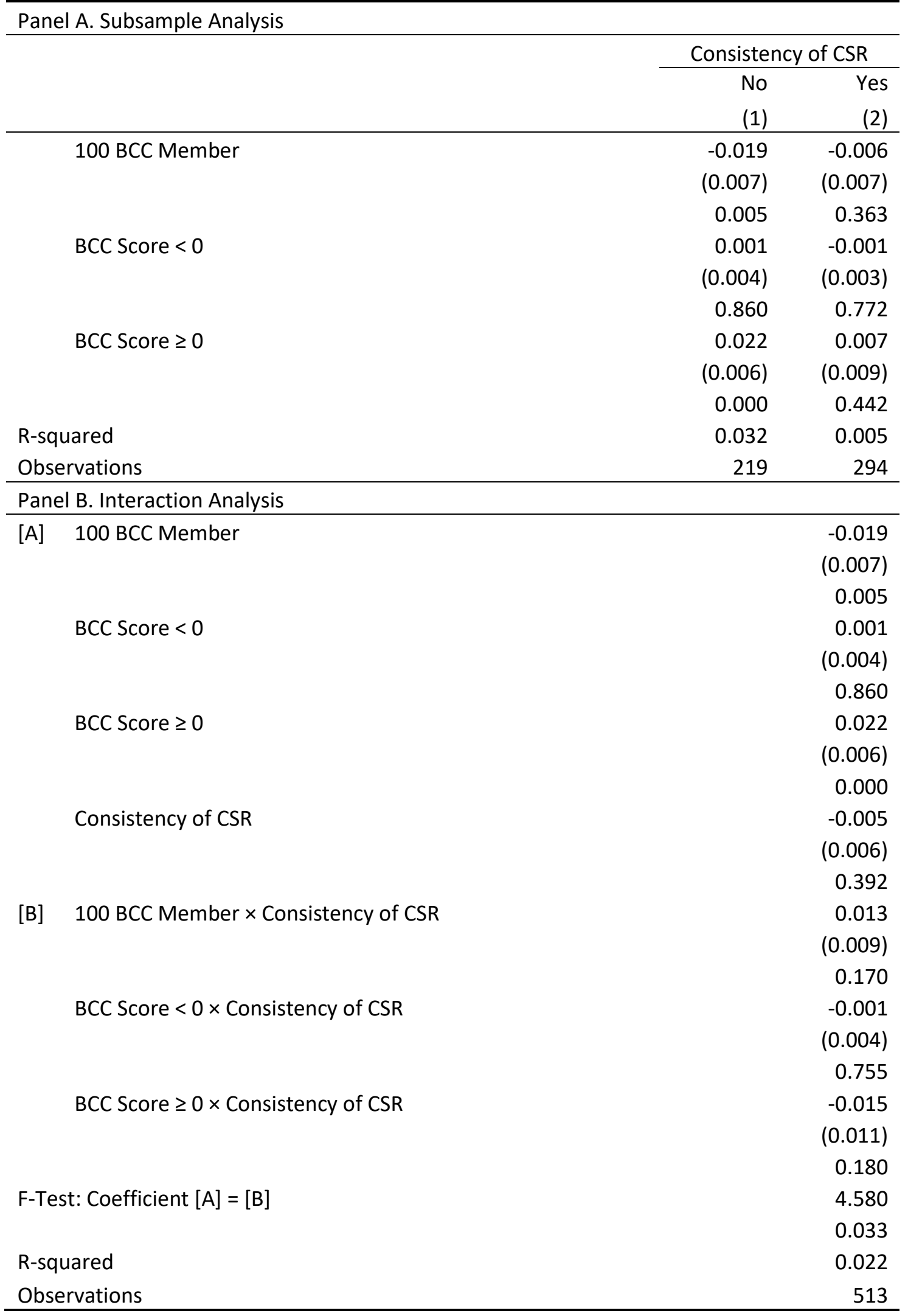


Table A9. Moderating Effects of Material CSR Investments

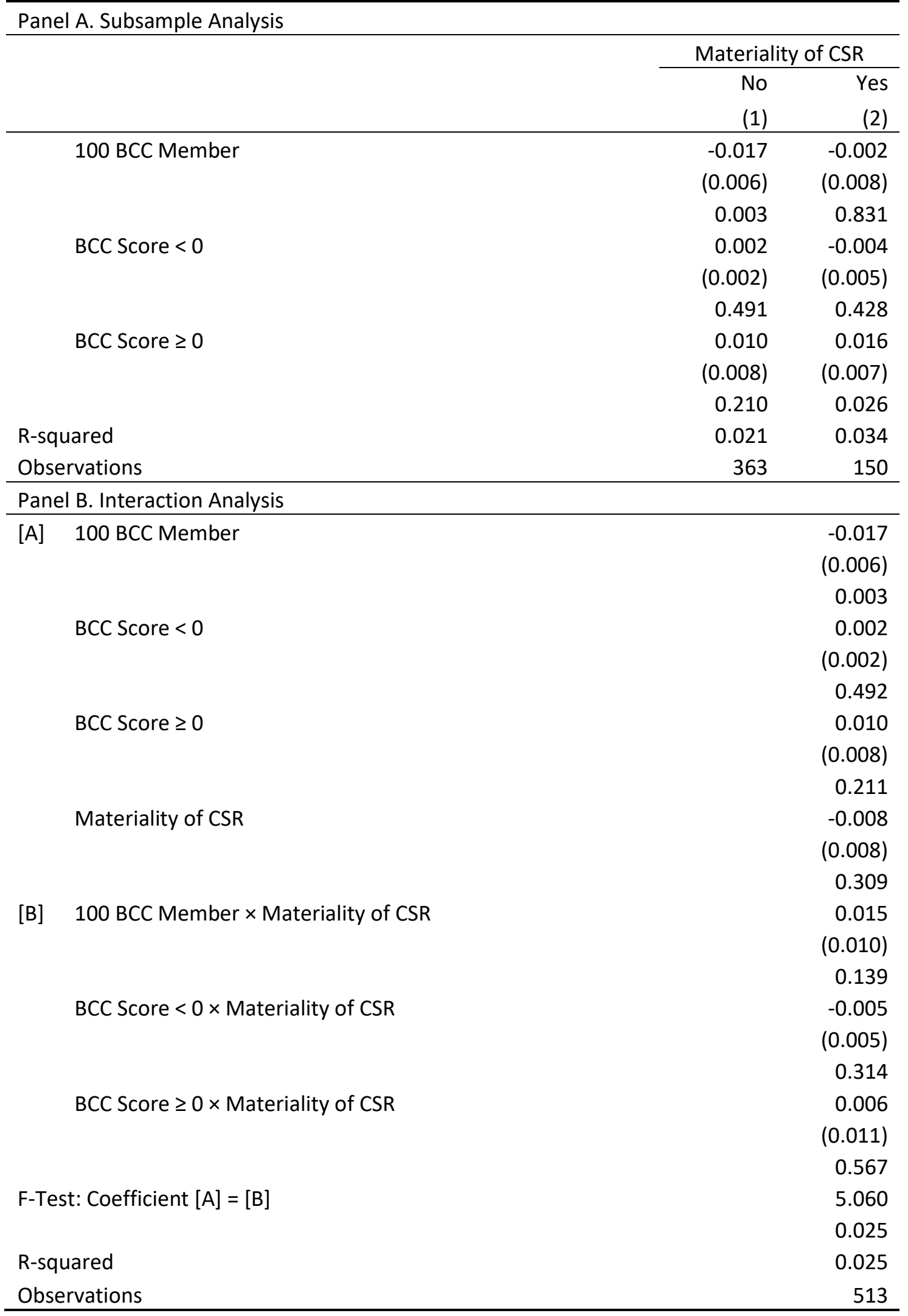




\begin{tabular}{|c|c|c|c|c|c|c|}
\hline & \multicolumn{3}{|c|}{$\begin{array}{c}\text { Difference-in-means: } 100 \text { BCC } \\
\text { Universe }\end{array}$} & \multicolumn{3}{|c|}{ Difference-in-means: Compustat Universe } \\
\hline & $\begin{array}{r}\text { Marginal } \\
\text { Firms } \\
{[-20,+20]}\end{array}$ & $\begin{array}{l}\text { Other } \\
\text { Firms }\end{array}$ & $p$-value & $\begin{array}{r}100 \mathrm{BCC} \\
\text { Sample }\end{array}$ & $\begin{array}{l}\text { Other } \\
\text { Firms }\end{array}$ & $p$-value \\
\hline & (1) & (2) & (3) & (4) & (5) & (6) \\
\hline Abnormal return on announcement day & 0.001 & -0.002 & 0.556 & -0.003 & -0.002 & 0.373 \\
\hline KLD index & 2.675 & 0.742 & 0.000 & 0.893 & 0.004 & 0.000 \\
\hline Total assets (log) & 8.514 & 8.509 & 0.986 & 18,698 & 2,245 & 0.000 \\
\hline Market value (log) & 8.660 & 8.400 & 0.348 & 17,471 & 1,415 & 0.000 \\
\hline ROA & 0.075 & 0.058 & 0.033 & 0.152 & 0.001 & 0.000 \\
\hline Cash & 0.086 & 0.070 & 0.333 & 0.078 & 0.184 & 0.000 \\
\hline Leverage & 0.232 & 0.267 & 0.145 & 0.268 & 0.243 & 0.001 \\
\hline Institutional ownership & 0.616 & 0.608 & 0.745 & 0.606 & 0.287 & 0.000 \\
\hline Analyst coverage & 20.125 & 20.918 & 0.685 & 20.856 & 4.138 & 0.000 \\
\hline DS 400 & 0.800 & 0.611 & 0.008 & 0.626 & 0.004 & 0.000 \\
\hline DJSI & 0.100 & 0.070 & 0.544 & 0.072 & 0.001 & 0.000 \\
\hline B2B industry & 0.700 & 0.708 & 0.914 & 0.708 & 0.801 & 0.000 \\
\hline
\end{tabular}

Notes: Columns (1)-(3) compare the subsample of firms close to (within 20 ranks of) the inclusion threshold with a subsample of non-close firms (more than 20 ranks away). Columns (4)-(6) compare the 100 BCC Sample with all other publicly listed firms in the Compustat database. P-values were generated using a two-sample t-test with unequal variances. 


\section{REFERENCES}

Angrist, J. D., \& Pischke, J.-S. (2009). Mostly harmless econometrics: An empiricist's companion. Princeton, NJ: Princeton University Press.

Angrist, J. D., \& Pischke, J.-S. (2015). Mastering 'metrics: The path from cause to effect. Princeton: Princeton University Press.

Chatterji, A. K., \& Toffel, M. W. (2010). How firms respond to being rated. Strategic Management Journal, 31(9), 917-945.

Cuñat, V., Gine, M., \& Guadalupe, M. (2012). The vote is cast: The effect of corporate governance on shareholder value. The Journal of Finance, 67(5), 1943-1977.

Flammer, C. (2015a). Does corporate social responsibility lead to superior financial performance? A regression discontinuity approach. Management Science, 61(11), 25492568.

Flammer, C. (2015b). Does product market competition foster corporate social responsibility? Evidence from trade liberalization. Strategic Management Journal, 36(10), 1469-1485.

Flammer, C. (2018). Competing for government procurement contracts: The role of corporate social responsibility. Strategic Management Journal, n/a-n/a.

Flammer, C., \& Bansal, P. (2017). Does a long-term orientation create value? Evidence from a regression discontinuity. Strategic Management Journal, 38(9), 1827-1847.

Flammer, C., \& Luo, J. (2017). Corporate social responsibility as an employee governance tool: Evidence from a quasi-experiment. Strategic Management Journal, 38(2), 163-183.

Jacob, R., Zhu, P., Somers, M.-A., \& Bloom, H. (2012). A practical guide to regression discontinuity. MDRC.

Khan, M., Serafeim, G., \& Yoon, A. (2016). Corporate sustainability: First evidence on materiality. The Accounting Review, 91(6), 1697-1724.

Lee, D. S., \& Lemieux, T. (2010). Regression discontinuity designs in economics. Journal of Economic Literature, 48(2), 281-355.

Madsen, P. M., \& Rodgers, Z. J. (2015). Looking good by doing good: The antecedents and consequences of stakeholder attention to corporate disaster relief. Strategic Management Journal, 36(5), 776-794.

Walls, J. L., Berrone, P., \& Phan, P. H. (2012). Corporate governance and environmental performance: Is there really a link? Strategic Management Journal, 33(8), 885-913. 